\title{
Electrodeposition of platinum on titanium felt in a rectangular channel flow cell
}

\author{
Luis F. Arenas, ${ }^{\mathrm{a}, *}$ Carlos Ponce de León, ${ }^{\mathrm{a}}$ Richard P. Boardman, ${ }^{\mathrm{b}}$ Frank C. Walsh ${ }^{\mathrm{a}, \mathrm{z}, * *}$ \\ ${ }^{a}$ Electrochemical Engineering Laboratory, Energy Technology Group, Faculty of Engineering and the \\ Environment, University of Southampton SO17 1BJ, UK. \\ ${ }^{\mathrm{b}} \mu$-VIS X-ray Imaging Centre, Faculty of Engineering and the Environment, University of \\ Southampton SO17 1BJ, UK. \\ ${ }^{z}$ Author for correspondence: F.C.Walsh@soton.ac.uk \\ * Electrochemical Society Student Member \\ ** Electrochemical Society Active Member
}

\begin{abstract}
Highly porous platinised titanium substrates are attractive electrode materials for industrial electrochemical processing and electrochemical energy storage. The electrodeposition of platinum on titanium felt was carried out in a divided, rectangular channel flow cell from an alkaline bath without additives. The morphology and spatial distribution of the platinum deposits in the porous material were analysed using SEM and EDS microscopy in addition to X-ray computed tomography (CT). The electroplated surface area was estimated from the charge transfer current ratio for $\mathrm{Ce}(\mathrm{IV})$ reduction and related to a theoretical electrosorbed hydrogen monolayer surface area. The platinised titanium felt showed a significant enhancement of active surface area in comparison to conventional electrode materials. Although platinum was present throughout the porous electrode, CT revealed heterogeneous deposits accumulating in regions near the membrane (during electrodeposition), as a result of the potential distribution in the felt material and flowing electrolyte. Uniform platinum coatings are possible on thin titanium felt under $200 \mu \mathrm{m}$ thick, by either potentiostatic or galvanostatic electrodeposition.
\end{abstract}

Keywords: computed tomography, felt, platinum, porous electrodes, titanium. (Approx. 8,050 words, 3 tables, 12 figures, 6 equations/reactions and 57 references). 


\section{Introduction}

The electrochemical redox of cerium ions in aqueous methanesulfonic acid (MSA) for industrial $^{1}$ and energy storage ${ }^{2}$ applications requires porous, flow-through platinised titanium $(\mathrm{Pt} / \mathrm{Ti})$ electrodes. These electrodes encompass high catalytic activity, corrosion resistance and low cost (in comparison to bulk platinum electrodes). Pt/Ti mesh electrodes have enabled the anodic production of $\mathrm{Ce}(\mathrm{IV})$ in flow reactors for the electrosynthesis of tetrahydroquinone ${ }^{3}$ and vitamin $\mathrm{K}_{3}{ }^{4}$ at a scale up to 400 tonnes per year, while Ce(IV) oxidant has been used in the nuclear decommissioning industry ${ }^{5}$ and in the disposal of hazardous organics. ${ }^{6}$

Recently, Pt/Ti mesh has been used as the positive electrode in a number of proposed ceriumbased redox flow batteries (RFBs). Such devices include: divided and undivided $\mathrm{Zn}-\mathrm{Ce},{ }^{2} \mathrm{~V}-$ $\mathrm{Ce}^{7-10}, \mathrm{~Pb}-\mathrm{Ce}^{11}, \mathrm{H}_{2}$-Ce half-fuel cell, ${ }^{12,13}$ and a Ce-Ce concentration cell ${ }^{14}$. In previous work, ${ }^{15}$ $\mathrm{Pt} / \mathrm{Ti}$ micromesh and $\mathrm{Pt} / \mathrm{Ti}$ felt electrodes were considered for the improvement of the $\mathrm{Zn}-\mathrm{Ce}$ RFB, quantifying the performance enhancement over mesh and planar electrodes for cerium ion redox:

$$
\mathrm{Ce}(\mathrm{III})-\mathrm{e}^{-} \rightleftarrows \mathrm{Ce}(\mathrm{IV}) \quad E^{\ominus}=+1.74 \mathrm{~V} v \text { s. SHE }
$$

The manufacture of Pt/Ti planar and mesh electrodes often involves the repeated immersion of titanium sheets in a solution followed by the thermal decomposition of the precursor in a furnace. ${ }^{16}$ DSA anodes for the chlor-alkali process can be manufactured on a large scale in this fashion while industrial Pt/Ti electrodes are often produced by electrodeposition of platinum on titanium after the application of a noble metal oxide inter-coating, typically $\mathrm{IrO}_{x} \cdot{ }^{17}$ On the other hand, electrodeposition of platinum from acid and alkaline plating baths is well-known and has many applications, ${ }^{18,19}$ such as anodes for electroplating of chromium and gold or 
cathodic protection of steel in seawater. Aqueous electrodeposition of platinum can be advantageous over more hazardous, unstable and costly solvents, such as amine complexes and ionic liquids. Similarly, electrodeposition in stirred and flowing baths is relatively simple in comparison to the more expensive chemical vapour deposition (CVP), physical vapour deposition (PVD), or the 'dip/spray and bake' methods which can prove wasteful of materials, difficult to control and tedious to scale-up.

This paper considers practical aspects of the electrodeposition of platinum on titanium felt in a filter-press flow cell. Such three-dimensional plated structures provide several advantages for a number of electrochemical technologies, ${ }^{17}$ including surface area enhancement and mass transport improvement. An alkaline plating solution was preferred over an acidic chloride bath in order to minimize hydrogen evolution. ${ }^{18}$ An advantage of this technique is that the plating solution flowing through the porous material reduces mass transport limitations. Additionally, this provides an alternative to the difficulties found when a material with small-size pores needs to be impregnated with a relatively viscous precursor and treated under non-uniform heating/cooling conditions. The electrodeposition of platinum using flow cells is unusual; two reported examples include a rectangular channel (breadth $10 \mathrm{~cm}$, length $18 \mathrm{~cm}$ ) Pt/Ti electrode mesh for a hydrodynamic study ${ }^{20}$ and a cylindrical (diameter $3 \mathrm{~mm}$, length $20 \mathrm{~mm}$ ) platinum plated reticulated vitreous carbon glucose sensor. ${ }^{21}$

$\mathrm{X}$-ray computed tomography $(\mathrm{CT})$ is well-suited to study the distribution of metal deposits on porous materials as well as the characteristics of the substrate itself, ${ }^{22}$ ranging from the macro to the micro scale. Examples of CT analysis applied to flow through electrodes include the porosity distribution of carbon-based gas diffusion layers (GDL) for fuel cells, ${ }^{23}$ porosity, surface area and mass transport properties of carbon felt for the all-vanadium RFB; ${ }^{.24,25}$ and the 
analysis of electrodeposited copper in a flow cell with reticulated vitreous carbon (RVC) electrodes. $^{26}$

\section{Experimental Details}

\subsection{Solutions}

The aqueous electroplating solutions were prepared at $22^{\circ} \mathrm{C}$ in batches of $50 \mathrm{~cm}^{3}$ by dissolving $20 \mathrm{~g} \mathrm{dm}^{-3}$ of hexachloroplatinic(IV) acid $\left(\mathrm{H}_{2} \mathrm{PtCl}_{6}\right)$ with a platinum mass fraction of approximately $40 \%$ (Fischer Scientific Ltd., UK) in a $0.1 \mathrm{~mol} \mathrm{dm}^{-3} \mathrm{NaOH}$ support electrolyte of $\mathrm{pH} 13 .{ }^{18}$ Deionized water of $4.3 \mu \mathrm{S} \mathrm{cm}{ }^{-1}$ conductivity was used. $\mathrm{H}_{2} \mathrm{PtCl}_{6}$ yields hexahydroxoplatinic(IV) acid $\left(\mathrm{H}_{2} \mathrm{Pt}(\mathrm{OH})_{6}\right)$ in alkaline media; ${ }^{27}$ the compound precipitates near neutral $\mathrm{pH}^{28}$ but the prepared orange coloured alkaline solutions showed complete stability throughout the experiments.

\subsection{Experimental arrangement}

The electrodeposition of platinum was performed using the experimental arrangement shown in Figure 1. The titanium felt was connected as cathode (negative electrode) in the twocompartment rectangular channel flow cell. Its components and dimensions have been described in a previous work. ${ }^{15}$ For convenience, the two half-cells were separated by a Nafion ${ }^{\circledR}$ 112 (Dupont Co, USA) ion exchange membrane. As shown in Figure 2, the negative flow channel was occupied by the titanium felt while the positive flow channel contained inert polypropylene meshes (internal aperture $4.6 \times 4.2 \mathrm{~mm}$, pitch $6.8 \times 8.0 \mathrm{~mm}$, thickness $1.3 \mathrm{~mm}$ ) in order to maintain a constant separation between the membrane and the Pt/Ti plate counterelectrode (CE). Such plastic meshes are usually called inert 'turbulence promoters' (ITP). Silicone rubber gaskets between the acrylic flow frames ensured hydraulic sealing via mechanical compression. The plating solution in the negative half-cell and the supporting 
electrolyte in the positive half-cell were recirculated via Masterflex L/S (Cole-Parmer Co, USA) peristaltic pumps. The electrolyte reservoirs were fitted with water jackets allowing temperature control within $\pm 0.5^{\circ} \mathrm{C}$ with the aid of a thermostatic water bath (Grant Instruments Ltd, UK). During potentiostatic electrodeposition, the cell was controlled with an Autolab potentiostat (Metrohm AG, The Netherlands). In this case, a three-electrode cell configuration was adopted with the felt as working electrode (WE) and the electrode potential was measured via Luggin capillary against a $\mathrm{Hg} \mid \mathrm{HgO}$ reference electrode. Galvanostatic coating was performed using an EX752M power supply (TT Instruments, UK). The two modes of electrical control are shown in Figure 1.

\subsection{Electrodeposition of platinum on titanium}

\section{$\underline{\text { Reduction of platinum }}$}

In aqueous alkali, the electrodeposition of platinum takes place from the reduction of $\mathrm{Pt}(\mathrm{IV})$ ions. ${ }^{18}$ The plating solution in this work was prepared using $\mathrm{H}_{2} \mathrm{PtCl}_{6}$ but $\mathrm{H}_{2} \mathrm{Pt}(\mathrm{OH})_{6}$ is the predominant $\mathrm{Pt}(\mathrm{IV})$ species as the high concentration of hydroxyl ions used $(\mathrm{pH}=13)$ shifts the following equilibrium to the right hand side: ${ }^{27}$

$$
\mathrm{H}_{2} \mathrm{PtCl}_{6}+6 \mathrm{OH}^{-} \rightleftarrows \mathrm{H}_{2} \mathrm{Pt}(\mathrm{OH})_{6}+6 \mathrm{Cl}^{-}
$$

The overall electrodeposition can be stated as:

$$
\mathrm{H}_{2} \mathrm{Pt}(\mathrm{OH})_{6}+4 \mathrm{e}^{-} \rightleftarrows \mathrm{Pt}+2 \mathrm{H}_{2} \mathrm{O}+4 \mathrm{OH}^{-}
$$


As pointed out by Hubbard and Anson ${ }^{29}$ and later by Yadav et al., ${ }^{30}$ hydrolysis intermediates of the form $\mathrm{H}_{2} \mathrm{Pt}(\mathrm{OH})_{x} \mathrm{Cl}_{6-x}$ could also be present in the solution in low concentration. In this case, the Pt(IV) overall reduction would be:

$$
\mathrm{Pt}(\mathrm{OH})_{x} \mathrm{Cl}_{6-x}{ }^{2-}+4 \mathrm{e}^{-} \rightleftarrows \mathrm{Pt}+x \mathrm{OH}^{-}+(6-x) \mathrm{Cl}^{-}
$$

The exact reduction mechanism of platinum ions in alkaline conditions has not been resolved in the literature but is likely to involve at least two steps. In contrast, it is known that Pt(IV) reduction takes place in two or three steps in acidic chloride baths. ${ }^{31}$

Hydrogen evolution is a common secondary reaction and causes low efficiencies during platinum electrodeposition:

$$
2 \mathrm{H}_{2} \mathrm{O}+2 \mathrm{e}^{-} \rightleftarrows \mathrm{H}_{2}+2 \mathrm{OH}^{-}
$$

By using alkaline baths with a $\mathrm{pH}$ of 10 , the current efficiency can reach approximately $50 \%{ }^{18}$

\section{Origin and manufacture of the electrodes}

The Pt/Ti felt electrode was constructed from a $3.6 \mathrm{~mm}$ thick sheet of sintered, diffusion bonded titanium fibres (NV Bekaert SA, Belgium). Individual fibres having irregular cross-sections, of which the longest side length is $42.3 \pm 4.4 \mu \mathrm{m}$, make up the bulk of the rigid material. The volumetric porosity, $\varepsilon$, of the felt is 0.80 and its average density is $0.88 \mathrm{~g} \mathrm{~cm}^{-3}$. The surface area per unit volume of the bare titanium felt was determined by CT to be approximately $255.8 \mathrm{~cm}^{-}$

1. The overall dimensions of the electrode were $60 \mathrm{~mm} \times 40 \mathrm{~mm} \times 3.6 \mathrm{~mm}$. The felt substrate to be electroplated was spot-welded to a $0.9 \mathrm{~mm}$ titanium plate in order to provide a reliable 
and current distributing electrical connection. A similar material, non-sintered Pt/Ti felt (surface area $60-90 \mathrm{~cm}^{-1}$, equivalent diameter 50-60 $\mu \mathrm{m}$ ), has been used by Olin Corp. as an electrode for the oxidation of sodium chlorite to chlorine dioxide. ${ }^{32}$ It is understood that $\mathrm{Pt} / \mathrm{Ti}$ felt is currently used in water electrolysers and has been evaluated for ozone generation, ${ }^{33} \mathrm{NH}_{3}$ electrosynthesis, ${ }^{34}$ and unitized reversible fuel cells. ${ }^{35}$ The Pt/Ti felt electrode here is compared to a commercial Pt/Ti plate (Magneto BV, The Netherlands) with a nominal platinum coating thickness of $3.5 \mu \mathrm{m}$, which is equivalent to a platinum loading of $7 \mathrm{mg} \mathrm{cm}^{-2}$. The Pt/Ti plate had a thickness of $3 \mathrm{~mm}$ and was plated on one side. The characteristics and dimensions of the electrodes are given in Table 1. Optical photographs can be found in a related work. ${ }^{15}$

\section{Etching of titanium felt}

Before electroplating, the titanium felt was chemically etched in a flowing solution containing $10 \%$ volume/weight of oxalic acid at $80{ }^{\circ} \mathrm{C} .{ }^{36}$ For this purpose, one of the hydraulic circuits of the system shown in Figure 1 was arranged so that the solution passed only through the single half-cell holding the material; no membrane or electrical connections were required. The etching solution was pumped until a dark brown colour developed, ${ }^{36}$ representing approximately 0.5 hour. Oxalic acid was used as an alternative to traditional hot $\mathrm{HCl}$ or $\mathrm{H}_{2} \mathrm{SO}_{4}$, to avoid the possibility of excessive dissolution of the fine titanium fibres, which has been observed previously. ${ }^{34}$ Additional stronger etching was applied before a second and third platinum electrodeposition step in order to improve the uniformity of the deposit. This involved an extended oxalic acid treatment for 4 hours (until brown colouration of the solution), followed by etching in $6.0 \mathrm{~mol} \mathrm{dm}^{-3} \mathrm{HCl}$ at $80{ }^{\circ} \mathrm{C}$ for 1 hour and in $1.0 \mathrm{~mol} \mathrm{dm}^{-3}$ aqueous $\mathrm{H}_{2} \mathrm{O}_{2}$ at $80{ }^{\circ} \mathrm{C}$ for 0.5 hour. No evidence of corrosion or mechanical deterioration of the felt was observed afterwards. The flow system was thoroughly cleaned with deionized water after each procedure. 


\section{Preparation of Pt/Ti felt electrodes}

The titanium felt underwent three electrodeposition steps. The first one was performed under constant potentiostatic control at $-0.2 \mathrm{~V} v s . \mathrm{Hg} \mid \mathrm{HgO}_{\text {(satd) }}$. A volume of $50 \mathrm{~cm}^{3}$ of the plating solution maintained at $75{ }^{\circ} \mathrm{C}$ was continuously pumped throughout the electrode at a mean linear velocity of $8 \mathrm{~cm} \mathrm{~s}^{-1}$, representing a Reynolds number of approximately 1355 . A summary of the electroplating conditions is given in Table 2 . The supporting electrolyte $\left(0.1 \mathrm{~mol} \mathrm{dm}^{-3}\right.$ $\mathrm{NaOH}$ ) flowed through the anodic half-cell at the same rate. During the electrodeposition, no significant hydrogen evolution was observed while the plating solution went from an orange colouration to colourless. At this point, profuse hydrogen evolution started and the cell was disconnected. The platinum ions in solution were completely consumed, as confirmed by negative tin(II) chloride and potassium iodide spot tests. ${ }^{37}$ The resulting electrode material was termed 'Pt/Ti felt A'.

As discussed in the results section, the platinum coverage after the previous procedure was low. Therefore, the same material was plated a second and third time under galvanostatic control at $100 \mathrm{~mA} \mathrm{~cm}^{-2}$ (based on the projected area of the electrode) after the additional chemical etching of the substrate. Flow and temperature conditions were the same as in the potentiostatic electrodeposition. Volumes of $50 \mathrm{~cm}^{3}$ and $100 \mathrm{~cm}^{3}$ of the plating solution were used during the second and a third plating steps and the resulting electrodes are referred to as 'Pt/Ti felt B' and 'Pt/Ti felt C', respectively.

\subsection{Analysis of coating morphology, composition and structural distribution}

Scanning Electrode Microscopy (SEM) and Energy Dispersive Spectroscopy (EDS)

SEM images of the prepared and supplied Pt/Ti materials were obtained using a JSM-6500F field emission electron microscope (Jeol Inc, USA). The elemental composition and presence 
of the coating on the substrate was determined from EDS mapping of the visible surface of samples of Pt/Ti felt C. Triangular samples of about $3.0 \mathrm{~mm} \times 3.0 \mathrm{~mm}$ sides were cut through the thickness of the material in the flow exit side. EDS images were obtained with an INCA XSight energy dispersive X-ray spectrometer (Oxford Instruments, U.K.) coupled to the electron microscope.

\section{$\underline{X-R a y ~ C o m p u t e d ~ T o m o g r a p h y ~(C T) ~}$}

CT scans were performed using a Zeiss Xradia 510 Versa X-ray microscope. Two different objective lenses were used to achieve the resolutions presented here; using the $4 \times$ objective yielded a resolution of $3.8 \mu \mathrm{m}$ per voxel, and the $20 \times$ objective gave a resolution of $753 \mathrm{~nm}$ per voxel. In each case, camera binning was set to $2 \times$, the filtration used was $350 \mu \mathrm{m}$ of $\mathrm{SiO}_{2}$, and the X-ray voltage was $80 \mathrm{kV}$ with a current of $87 \mu \mathrm{A}$. In the case of the $4 \times$ objective scan, the number of projections taken was 4001 , each with an exposure time of 2.5 seconds; for the $20 \times$ objective scan the projection count was 2201 with an exposure of 10 seconds. The fields of view were $3.8 \mathrm{~mm}$ and $0.75 \mathrm{~mm}$ for the $4 \times$ and $20 \times$ objectives respectively. The raw data images were processed using VGStudio MAX 2.1 CT visualisation software, developed by Volume Graphics GmbH (Germany). The surface area of the bare titanium felt was delimited using an ISO50\% threshold value. ${ }^{38}$

\subsection{Electrochemical performance and active area}

The electrochemical performance of the Pt/Ti felt electrodes towards the reaction of interest, $\mathrm{Ce}(\mathrm{IV})$ reduction, has been considered in detail in a complementary study and the volumetric mass transport coefficient, $k_{m} A_{e}$, for electrochemical reactors was determined as a function of the electrolyte mean linear flow velocity. ${ }^{15}$ Porous materials yielded values with orders of magnitude higher than those resulted from the platinised planar electrode. Here, the interest lies 
in the estimation of the platinum-coated surface area at the porous structures. Charge transfer current ratios for the reaction of interest and the estimation of a related theoretical hydrogen monolayer adsorption surface area were calculated for this purpose.

\section{Linear sweep voltammetry of the reaction of interest}

Linear sweep voltammetry was performed on each electrode in an electrolyte containing 0.1 mol dm ${ }^{-3} \mathrm{Ce}(\mathrm{IV})$ methanesulfonate and $0.7 \mathrm{~mol} \mathrm{dm}{ }^{-3} \mathrm{Ce}(\mathrm{III})$ methanesulfonate in $4.0 \mathrm{~mol} \mathrm{\textrm {dm } ^ { - }}$ ${ }^{3}$ methanesulfonic acid at $25{ }^{\circ} \mathrm{C}$. The potential scans were performed at $5 \mathrm{mV} \mathrm{s}^{-1}$ from -0.6 to $+0.9 \mathrm{~V}$ vs. $\mathrm{Hg} \mid \mathrm{Hg}_{2} \mathrm{SO}_{4 \text { (satd) }}$ in the case of the planar electrode, and from -0.2 to $+0.9 \mathrm{~V} v s$. $\mathrm{Hg} \mid \mathrm{Hg}_{2} \mathrm{SO}_{4(\text { satd) }}$ in the case of the felt electrodes. During experiments, the change in Ce(IV) concentration in the reservoir, as measured by volumetric titration of $\mathrm{Ce}(\mathrm{IV})$ against $\mathrm{Fe}(\mathrm{II}){ }^{39}$ was $<5 \%$ in all cases, and negligible for the plate electrode.

\section{Hydrogen electrosorption}

The electrode active area of the $24 \mathrm{~cm}^{2} \mathrm{Pt} / \mathrm{Ti}$ plate electrode for $\mathrm{H}$ adsorption was estimated through a classical cyclic voltammetry technique, ${ }^{40}$ using the theoretical value of the adsorption monolayer charge relationship factor of $210 \mu \mathrm{C} \mathrm{cm}^{-2}{ }^{41}$ Three representative sections of the electrode of $0.05 \mathrm{~cm}^{2}$ each were delimited with electroplating organic stop-off lacquer $\left(\right.$ Lacomit $^{\circledR}$ Ltd, UK) in order to obtain well-defined voltammograms, which are not observed with the full $25 \mathrm{~cm}^{2}$ surface. A three-electrode glass cell consisting on a tube $(1.5 \mathrm{~cm}$ internal diameter) with a gasketed flange to attach the electrode, was used. The $1.0 \mathrm{~cm} \times 1.0 \mathrm{~cm}$ Pt mesh counter-electrode was separated from the working electrode by a Nafion 112 ion exchange membrane and the solution was deoxygenated with $\mathrm{N}_{2}$ bubbling for 15 minutes. Afterwards, cyclic voltammetry was performed on these sections at $25^{\circ} \mathrm{C}$ in $1.0 \mathrm{~mol} \mathrm{dm}{ }^{-1}$ sulfuric acid at a 
linear sweep rate of $1.0 \mathrm{~V} \mathrm{~s}^{-1}$ between potentials of -0.65 and $+0.80 \mathrm{~V} v s . \mathrm{Hg} \mid \mathrm{Hg}_{2} \mathrm{SO}_{4 \text { (satd) }}$ until a stable response was observed.

The hydrogen electrosorption technique ${ }^{40}$ is useful in the determination of the roughness factor of planar platinum electrodes and the surface area of porous catalysts on 2-D supports. However, and in contrast to the Pt/Ti electrode described in the previous paragraph, this technique was not used in the case of the 3-D Pt/Ti felts due to the difficulty in determining the geometrical electrode area of small curved surfaces and/or plated porous bodies. As anticipated, attempts to analyse the felt electrodes by this technique produced capacitor-like voltammograms (not shown) due to the high currents resulting from their large surface area. As a result, the electrochemical performance of the felt electrodes was studied in terms of the reaction of interest (reduction of $\mathrm{Ce}(\mathrm{IV})$ ions in $\mathrm{MSA}$ ) and related to the $\mathrm{H}$ adsorption surface area on the planar Pt/Ti electrode (section 3.5).

\section{Results and Discussion}

\subsection{Macroscopic structure and deposit morphology (SEM images)}

SEM images of the $\mathrm{Pt} / \mathrm{Ti}$ felt $\mathrm{C}$ and $\mathrm{Pt} / \mathrm{Ti}$ plate electrodes at various magnifications are presented in Figure 3. The macroscopic external surface of the Pt/Ti felt $\mathrm{C}$ electrode is shown in Figure 3a). Numerous platinum nodules cover the individual fibres, which lie predominantly across to the X-Z plane (see Figure 2). This surface was adjacent to the membrane during the electrodeposition, parallel to the current collector and perpendicular to the overall plating solution flow direction. In comparison, the commercially supplied Pt/Ti plate, shown in Figure 3d), has a uniform coating on a texturized flat titanium substrate. 
The microstucture of the platinum deposit on the $\mathrm{Pt} / \mathrm{Ti}$ felt $\mathrm{C}$ electrode is shown at a fibre junction in Figure 3b). The two platinum nodules shown in the figure have a diameter close to $30 \mu \mathrm{m}$, and are analogous to those covering the length of the fibres. In some regions, the felt is densely, but incompletely, covered by platinum nuclei of $<1 \mu \mathrm{m}$ diameter. Morphologically similar platinum nodules, have been observed on a RVC electrode coated from a non-stirred $5.0 \times 10^{-3} \mathrm{~mol} \mathrm{dm}^{-3}$ platinum solution in $0.1 \mathrm{~mol} \mathrm{dm}^{-3}$ sulfuric acid. ${ }^{33}$ The coating of the $\mathrm{Pt} / \mathrm{Ti}$ plate, Figure 3e), is formed by overlapping platinum nodules of $<5 \mu \mathrm{m}$ approximate diameter.

At higher magnifications $(10,000 \times)$, the platinum nucleation on the titanium fibres clearly differs from that observed at the Pt/Ti plate electrodes. The nucleation at the Pt/Ti felt can be seen in Figures 3c) and shows directional growths, each crystal grain having dimensions $<0.2$ $\mu \mathrm{m}$. This can be contrasted with the hemispherical nucleation of platinum observed at a carbon fibre in diluted acid chloride solutions. ${ }^{42}$ The platinum nucleation at the Pt/Ti plate electrode, seen in Figure $3 \mathrm{f}$ ), is characterised by rounded $\approx 0.1 \mu \mathrm{m}$ protrusions, probably due to electrolyte additives.

The progressive platinum coverage of the external surface of the felt electrode following the second and third electroplating steps is clearly seen in the SEM images of Figure 4, corresponding to an increasing platinum loading. The Pt/Ti felt A was incompletely covered by sparsely distributed platinum nodules having a diameter between 20 and $50 \mu \mathrm{m}$, as shown in Figure 4a). The morphology of the outer surface of the intermediate Pt/Ti felt B, seen in Figure 4b), presents a higher density of nodules fused together. Pt/Ti felt C in Figure 4c) displays the highest platinum content, with most of the individual fibres covered by merged platinum nodules, although the coverage seems to decrease on the fibres in the interior of the material. 
The platinum deposit distribution in the interior of the Pt/Ti felt $\mathrm{C}$ electrode was also studied along a cross-section cut, following a straight-line section between the membrane and the negative current collector ( $\mathrm{Y}$ axis in Figure 2). Figure 5 shows the general appearance of the platinum deposits at different distances from the membrane plane. The number of platinum growths decreases from a maximum at the external surface of the electrode near the membrane, Figure 5a), to a minimum next to the current collector, Figure 5e), respectively. Figures 5b), 5c) and 5d) show the intermediate stages. This was corroborated by the CT images described below.

The morphology of platinum on porous titanium materials could be optimised by controlling several factors: electrodeposition current density/potential, plating additives, surface preparation, controlled deposition time, as well as uniform current density and potential across the electrode surface. This is demonstrated by the electrodeposition of noble metals on small samples of porous electrodes were the current and potential distribution is practically homogeneous. For instance, titanium felt (thickness $100 \mu \mathrm{m}$, fibre diameter $15 \mu \mathrm{m}$, porosity $40 \%$, BET specific surface area $717 \mathrm{~cm}^{2} \mathrm{~g}^{-1}$ ) has been uniformly coated with ruthenium microgranular catalysts from sulfuric acid stirred solutions at $75{ }^{\circ} \mathrm{C}$ and $48 \mathrm{~mA} \mathrm{dm}{ }^{-2} \cdot{ }^{34}$ These and similar ruthenium coatings studied by EDS images revealed the significant effect of temperature, current density and etching conditions. Using a flowing electrolyte, uniform platinum deposits on reticulated vitreous carbon permitted to build a small glucose sensor, ${ }^{21}$ while highly smooth uniform palladium deposits have been obtained on the same substrate. ${ }^{43}$

\subsection{Composition of electrodeposit and substrate (EDS analysis)}

The elemental composition of the electrodeposited coating and the underlying substrate was determined from their EDS spectra. Figures 6a) and 6b) show the characteristic peaks for 
platinum and titanium observed at a region of the Pt/Ti felt A shown in Figure 6c). EDS analysis was further exploited in order to assess the homogeneousness of platinum coverage at the felt porous structures. Figure 7 provides an SEM image and a EDS elemental mapping of a sample of the Pt/Ti felt $\mathrm{C}$ electrode. The base of the sample in the figure was closest to the current collector and the top was closest to the membrane during electrodeposition. Cross-sections of the electrode thickness can be seen at both sides of the triangular volume shown in Figure 7a). The platinum and titanium EDS maps shown in Figures 7b) and 7c), respectively, indicate that the top plane consists mostly of fully coated fibres. Meanwhile, exposed zones of the titanium substrate can be seen over the cross-section of the electrode (at the sides of the sample), together with some platinum, which appears to be present in concentrated spots. This suggest that $\mathrm{Pt} / \mathrm{Ti}$ felt $\mathrm{C}$ electrode was preferentially coated with platinum next to membrane, although small portion of the precious metal seem to be present through the whole electrode, despite large zones of exposed titanium felt.

\subsection{Structure of the porous materials and internal Pt distribution (CT imaging)}

The distribution of platinum in the porous electrode structures was determined by X-ray CT. Platinum and titanium have considerably different atomic numbers, resulting in welldifferentiated images. CT images of volume samples of bare titanium felt and of the Pt/Ti felt $\mathrm{C}$ electrode are presented in Figures 8a) and 8b), respectively. The open, porous nature of the flow-through electrode material can be observed clearly together with a uniform distribution of fibres. In the case of the $\mathrm{Pt} / \mathrm{Ti}$ felt $\mathrm{C}$ electrode, Figure $8 \mathrm{~b}$ ), $\mathrm{CT}$ reveals a high concentration of platinum electrodeposits on the fibres in the planes adjacent and close to the ion exchange membrane in the flow cell, consistent with SEM and EDS images. The interior of the electrode is populated by a few platinum nodules, which can also be observed in Figure 5. Less platinum is observed in the bulk of the uncoated felt region in the CT image compared to the EDS 
mapping due to the resolution of the technique, which might not detect smaller platinum nuclei. A CT scan of the region with maximum platinum coverage at a higher magnification permits to evaluate the coating layer surrounding the individual fibres. The cross-sectional view (Y-Z) in Figure 9a) shows a heterogeneous agglomeration of platinum nodules on the outermost fibres. Some of the fibres below show a platinum layer of variable thickness, which decreases as the fibres are further away from the top plane. Some nodules in the lower regions can also be seen. The view of one of the X-Z planes approximately $120 \mu \mathrm{m}$ below the fibres next to the membrane is shown in Figure 9b). Individual fibres covered by platinum layers and isolated nodules appear randomly on this part of the electrode. A cross-sectional CT image of the plated felt electrode body is shown Figure 10, where platinum appears as bright green features. The average thickness of the platinum coated region is $<200 \mu \mathrm{m}$. Although some platinum nodules appear in lower regions, most of the titanium felt remained uncoated.

\subsection{Origin of the heterogeneous platinum electrodeposition}

The preferential deposition of the precious metal in the planes situated near the membrane during the electrodeposition process is explained by the effect of current and potential distribution at both the metal and electrolyte phases on the nucleation of platinum. As shown by Langlois et al., ${ }^{44}$ who assumed a highly conductive electrode, the potential in the electrolyte flooding a porous cathode (negative half-cell) in a rectangular channel flow cell is at its maximum next to the membrane, decreasing as a function of distance towards its current collector. Such configuration for a membrane divided cell with parallel plate electrodes is identical the presented in Figure 2a). Masliy et $a l^{45,46}$ have further considered the current distribution through the metallic matrix, showing that the simplified current distribution predominates unless high conversion rates are archived at the electrode (e.g., at high current densities). In that case, the deposit distribution changes significantly along the length of the 
electrodes in the flow direction. The same authors have also modelled the undesired extreme case of electrode blockage by a metal deposit. ${ }^{47}$

Still, the observed distribution of platinum cannot be explained solely by the potential/current density gradient. The quantity of platinum on the substrate does not appear to decrease in a smooth, exponential transition across the thickness of the electrodes as demanded by the current distribution and Faraday's laws. Instead, platinum deposits seem to follow initial nucleation sites. Nucleation takes place in the high potential regions near the membrane at the beginning of the electrodeposition, establishing dominant growth paths. Yasin et al. ${ }^{42}$ have noted the strong dependence of platinum growth on overpotential nucleation, which continues during the rest of the electrodeposition and forms hemispherical nodules. This also occurs in nodular growths sporadically distributed away from the membrane, which are most likely the result of impurities or local edge effects that reduce the nucleation overpotential.

The heterogeneous distribution of platinum was not an impediment to the use of Pt/Ti felt electrodes in a flow reactor, ${ }^{15}$ showing excellent limiting current enhancement factors of up to 160 for the reduction of $\mathrm{Ce}(\mathrm{IV})$ ions in comparison to the Pt/Ti planar electrode. We anticipate a significantly higher performance for fully coated materials. In industrial and energy storage applications, the incomplete platinum coverage will have consequences on the stability of the material. During anodic operation, e.g. in industrial Ce(IV) generation, ${ }^{1}$ incomplete platinum deposits could exfoliate, although the passivation of titanium could provide an acceptable lifetime for the material. However, during cathodic operation, e.g. the discharge of a Ce-based redox flow battery, ${ }^{2}$ the uncoated titanium in the electrode will be susceptible to cathodic corrosion, especially under repeated cycling between the anodic and cathodic regimes. 
The preferential deposit of platinum at the felt electrode region next to the membrane, were the potential in the solution is higher, ${ }^{44}$ can be compared to a platinised RVC structure in the amperometric glucose sensor reported by Heider et $a l .{ }^{21}$ Likewise, 2-dimensional X-ray images of the material revealed a heterogeneous platinum deposition driven by a potential gradient. More platinum was deposited from the phosphate buffer solution in the RVC region close to the counter-electrode in their undivided flow cell. The deposits appear to be more uniform than the titanium felt, probably due to the low current density $\left(0.1 \mathrm{~mA} \mathrm{~cm}{ }^{-2}\right.$ calculated from an estimated volumetric surface area) applied over an extended period of 18 hours.

Regarding the practical implications of the potential distribution profile through the porous electrodes in the electrodeposition of metals in large flow cells, it is worth noting the previous literature. The same heterogeneous deposit effect is clearly shown in the study of an early Zn$\mathrm{Br}_{2}$ flow battery. ${ }^{48} \mathrm{X}$-ray radiographs of cross sections of the $10 \mathrm{~cm} \times 10 \mathrm{~cm}$ RVC electrodes show that zinc electrodeposits concentrated in the plane closer to the positive electrode reaching depths of $\sim 1 \mathrm{~mm}$ regardless the electrolyte flow rate. The reported images resemble Figure 10 . A similar behaviour was verified in a flow cell for zinc removal, ${ }^{49}$ were 2 -dimensional X-ray tomography images of electrode planes at different depths showed that the metal deposit layer had a thickness of $c a .1 .5 \mathrm{~mm}$. In addition to our results, these works suggest that only thin porous electrodes can be uniformly plated in flow cells. The scale-up of an industrial electrodeposition process based on this technique might be limited to thin porous structures plated for long times at low current densities. The electrodeposition of platinum could be improved by promoting nucleation at more negative potentials, applying longer deposition times and using suitable plating additives. It is known that a thin ceramic undercoating improves the adhesion and distribution of the electrodeposited platinum. ${ }^{17}$ Bipolar electrodeposition, ${ }^{50}$ pulse electrodeposition, ${ }^{51}$ and ultrasound-aided electrodeposition ${ }^{52}$ from flowing plating 
solutions could significantly improve this method. However, platinum electroless deposition ${ }^{19}$ and chemical vapour deposition ${ }^{53}$ on porous titanium substrates might be especially useful for obtaining uniformly-coated porous materials.

\subsection{Estimation of the active electrochemical surface area}

In order to obtain an estimation of the active electrode area, $A_{a}$, of the $\mathrm{Pt} / \mathrm{Ti}$ felt electrodes, the reduction current for $\mathrm{Ce}(\mathrm{IV})$ ions at the charge-transfer region was related to that achieved at the Pt/Ti planar electrode. Since the current, $I_{C T}$, developed under full charge-transfer control at a specific overpotential value near the open circuit potential is directly proportional to the active electrode area, $A_{a}$, it follows that the area of porous electrodes can be related to that of a plate by the ratio of their currents. In these conditions, mass transport has no effect on the electrode current which is given by: ${ }^{54}$

$I_{C T}=z F A_{a} k c \exp (\alpha z F \eta / R T)$

Table 3 presents the approximate charge transfer current ratio of the porous electrodes to the Pt/Ti plate electrode, $\Psi$, determined by this method from the linear sweep voltammetry for $\mathrm{Ce}(\mathrm{III}) / \mathrm{Ce}(\mathrm{IV})$ shown in Figure 11. The ratios were calculated from the average values of opencircuit potential and reduction current; their mean and standard deviation is given in Table 3. The charge transfer current ratios suggest that the platinum-covered area in the Pt/Ti felt $\mathrm{C}$ electrode is approximately 20.4 times larger than on the plate.

In order to express $A_{a}$ for the various electrodes against a common standard, the current ratios for $\mathrm{Ce}(\mathrm{IV})$ reduction were used to relate the experimental value of $A_{a}$ for $\mathrm{H}$ adsorption of the $\mathrm{Pt} / \mathrm{Ti}$ plate electrode to a theoretical $A_{a}$ for $\mathrm{H}$ adsorption at the platinised felt electrodes. It is assumed that the platinum active electrode area $A_{a}$ maintains the same proportion as with the 
$\mathrm{Ce}(\mathrm{III}) / \mathrm{Ce}(\mathrm{IV})$ redox couple and that the $\mathrm{H}$ adsorption behaviour is the same at the plate and felt electrode. Considering the well-known charge to area relationship of $\mathrm{H}$ absorption in 1.0 mol dm ${ }^{-3}$ sulfuric acid, ${ }^{40}$ the roughness factor of the Pt/Ti plate was determined to be $31.2 \pm 0.7$, which is a typical value for non-polished, planar electrodes. The related voltammogram is shown in Figure 12. The value of $A_{a}$ for the whole electrode was obtained by multiplying its projected geometrical area, $A,\left(24 \mathrm{~cm}^{2}\right)$ by the roughness factor, see Table 3 .

The corresponding surface area for $\mathrm{H}$ adsorption at the felt electrodes is presented in Table 3 . The real active area for $\mathrm{H}$ absorption of the $\mathrm{Pt} / \mathrm{Ti}$ plate is $748.8 \pm 16.8 \mathrm{~cm}^{2}$, and the estimated value for the $\mathrm{Pt} / \mathrm{Ti}$ felt $\mathrm{C}$ is $\approx 15,300 \mathrm{~cm}^{2}$. As mentioned in the experimental section, the real $\mathrm{H}$ adsorption was not measured at the felt electrodes in view of difficulties in cutting or insulating a small section of precisely known electroplated geometrical area, which is further complicated by their curved porous surfaces; hence the extrapolation approach. The $\mathrm{H}$ absorption technique is unsuitable for such relatively large $\left(25 \mathrm{~cm}^{2}\right.$ projected area) electrodes.

The charge-transfer current ratios approach to $A_{a}$ estimation has several limitations. The determination of $I_{C T}$ at $\eta=-20 \mathrm{mV}$ from the equilibrium potential of each electrode has an error of up to $13 \%(\mathrm{Pt} / \mathrm{Ti}$ felt $\mathrm{B})$ and an error of up to $14 \%(\mathrm{Pt} / \mathrm{Ti}$ felt $\mathrm{C})$ due to the variation in multiple linear sweep experiments. Indeed, the estimation of accurate and precise $A_{a}$ in large electrodes for flow cells is problematic. For instance, $A_{a}$ could be determined for the $\mathrm{Zn}-\mathrm{Br}_{2}$ battery developed at Sandia National Laboratories (planar electrodes) with an accuracy of only $20 \%$ from capacitance measurements using cyclic voltammetry, ${ }^{55}$ provided a proportionality constant related to electrolyte composition and electrode material. Our approach based on $I_{C T}$ ratios is simpler and can yield comparable error margins. Meanwhile, the surface area measured by BET provides an inaccurate, high (electrochemical) active area, ${ }^{56}$ although it is useful for 
comparisons. Real surface area measurements are known to depend on methodology, adsorbate stoichiometry, active species, electrolyte properties, etc. ${ }^{40}$ For instance, the roughness factor of Pt catalysts determined with $\mathrm{Ag}$ adsorption is nearly $50 \%$ that for $\mathrm{H}$ adsorption. ${ }^{57}$ There are practical advantages in treating $k_{m} A_{e}$ as a product in electrochemical flow reactors, rather than attempting to elucidate separate $k_{m}$ and $A_{e}$ values when studying porous electrodes in applied settings. $k_{m} A_{e}$ as a function of flow rate at the studied $\mathrm{Pt} / \mathrm{Ti}$ electrodes is given in complementary research. ${ }^{15}$ This performance factor is relevant to electrochemical reactor design. $^{44}$

\section{Conclusions}

- Platinised-titanium porous electrodes with high catalytic activity and high surface area can be prepared by electrodeposition in flow cells using alkaline plating solutions. Either potentiostatic or galvanostatic modes are possible. This rapid, convenient, and low waste technique can be applied at laboratory and medium-size scales.

- The platinum coverage of the studied $3.6 \mathrm{~mm}$ thick Pt/Ti felt is non-uniform, concentrating in the plane adjacent to the membrane and decreasing significantly as a function of the distance towards the current collector.

- Heterogeneous platinum deposition in the interior of porous electrodes takes place as a result of the potential drop at the electrolyte phase and electrode material along the thickness of the electrode in parallel plate flow cells.

- Thinner porous titanium materials (e.g. felt $<0.2 \mathrm{~mm}$ thick) are more suitable for electrodeposition processes in a flow cell resulting in uniform platinum coatings. Such materials would also reduce electrode volume and hydraulic pressure drop losses.

- In order to fully-coat relatively thick porous electrodes, low pulsated current densities applied over an extended time could be more suitable in flow cells. Otherwise, 
alternative methods such as bipolar deposition in stirred baths or electroless deposition should be used.

- Platinised titanium felts can be used to increase the yield of electrochemical filter-press reactors in several applications, including: redox flow batteries, water electrolysers, unitized reversible fuel cells, electrosynthesis cells and environmental remediation processes.

\section{Acknowledgements}

LFA gratefully acknowledges the funding provided by CONACYT and SEP scholarships and the support of the Research Institute for Industry of the University of Southampton. The authors gratefully acknowledge collaboration with the $\mu$-VIS centre at the University of Southampton for provision of tomographic imaging facilities, supported by an EPSRC grant EP-H01506X. All data supporting this study are openly available from the University of Southampton repository at http://doi.org/10.5258/SOTON/403805. 


\section{References}

1. L. F. Arenas, C. Ponce de León, and F. C. Walsh, Electrochim. Acta, 205, 226-247 (2016).

2. F. C. Walsh, C. Ponce de León, L. Berlouis, G. Nikiforidis, L. F. Arenas-Martínez, D. Hodgson, and D. Hall, ChemPlusChem, 80, 288-311 (2015).

3. S. Harrison and A. Théorêt, J. New Mat. Electrochem. Systems, 2, 1-9 (1999).

4. Lonza Group Company History, http://www.lonza.com/about-lonza/companyprofile/company-history.aspx (accessed November 18, 2016).

5. J. Ishii, F. Kobayashi, S. Uchida, M. Sumiya, and U. Miki, in, vol. 44, Tokyo (2011).

6. J. A. Varela, S. G. Oberg, T. M. Neustedter, and N. Nelson, Environmental Progress, 20, 261-271 (2001).

7. B. Fang, S. Iwasa, Y. Wei, T. Arai, and M. Kumagai, Electrochim. Acta, 47, 3971-3976 (2002).

8. Y. Liu, X. Xia, and H. Liu, J. Power Sources, 130, 299-305 (2004).

9. P. K. Leung, M. R. Mohamed, A. A. Shah, Q. Xu, and M. B. Conde-Duran, J. Power Sources, 274, 651-658 (2015).

10. V. Amstutz, K. E. Toghill, F. Powlesland, H. Vrubel, C. Comninellis, X. Hu and H. H. Girault, Energy Environ. Sci., 7, 2350-2358 (2014).

11. Z. Na, S. Xu, D. Yin, and L. Wang, J. Power Sources, 295, 28-32 (2015).

12. H. M. H. Dewage, B. Wu, A. Tsoi, V. Yufit, G. J. Offer and N. Brandon, J. Mater. Chem. A, 3, 9446-9450 (2015).

13. M. C. Tucker, A. Weiss, and A. Z. Weber, J. Power Sources, 327, 591-598 (2016).

14. R. Zito, Energy Storage: A New Approach, John Wiley \& Sons, Hoboken (NJ), (2010).

15. L. F. Arenas, C. Ponce de León, and F. C. Walsh, Electrochim. Acta, 221, 154-156 (2016).

16. P. C. S. Hayfield, Platinum Metals Rev., 42, 46-55 (1998).

17. G. K. Chandler, J. D. Genders, and D. Pletcher, Platinum Metals Rev., 41, 54-63 (1997).

18. M. E. Baumgärter and C. J. Raub, Platinum Metals Rev., 32, 188-197 (1988).

19. C. R. K. Rao and D. C. Trivedi, Coord. Chem. Rev., 249, 613-631 (2005).

20. U. M. López-García, P. E. Hidalgo, J. C. Olvera, F. Castañeda, H. Ruiz, G. Orozco, Fuel, 110, 162-170 (2013).

21. G. H. Heider, S. V. Sasso, K. Huang, A. M. Yacynych, and H. J. Wieck, Anal. Chem., 62, 1106-1110 (1990). 
22. E. Maire, Annu. Rev. Mater. Res., 42, 163-178 (2012).

23. Z. Fishman, J. Hinebaugh, and A. Bazylak, J. Electrochem. Soc., 157, B1643-B1650 (2010).

24. G. Qiu, A. S. Joshi, C.R. Dennison, K.W. Knehr, E.C. Kumbur, Y. Sun, Electrochim. Acta, 64, 46-64 (2012).

25. G. Qiu, C. R. Dennison, K. W. Knehr, E. C. Kumbur, and Y. Sun, J. Power Sources, 219, 223-234 (2012).

26. O. G. Olvera and G. T. Lapidus-Lavine, Int. J. Chem. React. Eng., 10, article A36 (2012).

27. P. Patnaik, Handbook of Inorganic Chemicals, McGraw-Hill, New York, (2003).

28. J. P. Heffer, Process for preparing platinum group metal catalysts, US Patent 4,324,700 (1982).

29. A. T. Hubbard and F. C. Anson, Anal. Chem., 38, 1887-1893 (1966).

30. J. B. Yadav, J.-W. Park, Y.-J. Cho, and O.-S. Joo, Int. J. Hydrogen Energy, 35, 10067$10072(2010)$.

31. B. Gollas, J. M. Elliott, and P. N. Bartlett, Electrochim. Acta, 45, 3711-3724 (2000).

32. J. Kaczur, L. L. Scott, and R. L. Dotson, in Proceedings of the 11th International Forum on Electrolysis in the Chemical Industry: Electrochemical Processing Technologies, p. 116, Clearwater Beach, FL (USA) November 2-6 (1997).

33. M. I. Awad, M. M. Saleh, and T. Ohsaka, J. Electrochem. Soc., 153, D207-D212 (2006).

34. K. Kugler, M. Luhn, J. A. Schramm, K. Rahimi, and M. Wessling, Phys. Chem. Chem. Phys., 17, 3768-3782 (2015).

35. C. M. Hwang, M. Ishida, H. Ito, T. Maeda, A. Nakano, Y. Hasegawa, N. Yokoi, A. Kato, T. Yoshida, Int. J. Hydrogen Energy, 36, 1740-1753 (2011).

36. C. H. Angell, Surface treatment of titanium, US Patent 3,650,861 (1972).

37. F. Feigl and V. Anger, Spot Tests in Inorganic Analysis, 6 ed., Elsevier, Amsterdam, (2012).

38. K. Kiekens, F. Welkenhuyzen, Y. Tan, P. Bleys, A. Voet, J.-P. Kruth and W. Dewulf, Meas. Sci. Technol., 22, article 115502 (2011).

39. P. Patnaik, Dean's Analytical Chemistry Handbook, McGraw Hill Professional, (2004).

40. S. Trasatti and O. A. Petrii, Pure Appl. Chem., 63 (1991).

41. T. Biegler, D. A. J. Rand, and R. Woods, J. Electroanal. Chemistry Interfacial Electrochem., 29, 269-277 (1971).

42. H. M. Yasin, G. Denuault, and D. Pletcher, J. Electroanal. Chem., 633, 327-332 (2009). 
43. M. Łukaszewski, A. Żurowski, and A. Czerwiński, J. Power Sources, 185, 1598-1604 (2008).

44. S. Langlois and F. Coeuret, J. Appl. Electrochem., 20, 740-748 (1990).

45. A. I. Masliy, N. P. Poddubny, A. Z. Medvedev, and V. O. Lukyanov, J. Electroanal. Chem., 757, 128-136 (2015).

46. A. I. Maslii, N. P. Poddubnyi, and A. Z. Medvedev, Russ. J. Electrochem., 52, 576-583 (2016).

47. A. I. Masliy and N. P. Poddubny, in Metal Electrodeposition, M. Nuñez, Editor, p. 99128, Nova Science Publishers, New York (2005).

48. C. D. Iacovangelo and F. G. Will, J. Electrochem. Soc., 132, 851-857 (1985).

49. M. R. V. Lanza and R. Bertazzoli, J. Appl. Electrochem., 30, 61-70 (2000).

50. C. A. C. Sequeira, D. S. P. Cardoso, and M. L. F. Gameiro, Chemical Engineering Communications, 203, 1001-1008 (2016).

51. M. S. Chandrasekar and M. Pushpavanam, Electrochim. Acta, 53, 3313-3322 (2008).

52. C. T. J. Low, R. G. A. Wills, and F. C. Walsh, Surf. Coat. Technol., 201, 371-383 (2006).

53. M. J. Rand, J. Electrochem. Soc., 120, 686-693 (1973).

54. R. Guidelli, R. G. Compton, J. M. Feliu, E. Gileadi, J. Lipkowski, W. Schmickler and S. Trasatti, Pure Appl. Chem., 86, 245-258 (2014).

55. N. J. Magnani, R. P. Clark, J. W. Braithwaite, D. M. Bush, P. C. Butler, J. M. Freese, K. R. Grothaus, K. D. Murphy, P. E. Shoemaker, Exploratory battery technology development and testing report for 1985, SAND86-1266, Sandia National Laboratories, Albuquerque, NM (1987).

56. J. M. Marracino, F. Coeuret, and S. Langlois, Electrochim. Acta, 32, 1303-1309 (1987).

57. M. J. Watt-Smith, J. M. Friedrich, S. P. Rigby, T. R. Ralph, and F. C. Walsh, J. Phys. D: Appl. Phys., 41, 174004 (2008). 


\section{Nomenclature}

Symbol

Meaning

Units

Geometrical electrode area

$\mathrm{cm}^{2}$

$A_{a}$

Active electrode area

$\mathrm{cm}^{2}$

$A_{e}$

Volumetric active electrode area

$\mathrm{cm}^{-1}$

B

Flow channel breadth

$\mathrm{cm}$

C

Reactant concentration

$\mathrm{mol} \mathrm{dm}{ }^{-3}$

$d_{e}$

Equivalent diameter of flow channel $\left(d_{e}=2 B S /(B+S)\right)$

$\mathrm{cm}$

$E_{0}$

Equilibrium potential

V

F

Faraday constant

$\mathrm{C} \mathrm{mol}^{-1}$

$I_{C T}$

Charge transfer current

A

$k$

Electron transfer rate

$\mathrm{cm}^{3} \mathrm{~mol}^{-1} \mathrm{~cm}^{-1}$

$k_{m}$

Mass transport coefficient

$\mathrm{cm} \mathrm{s}^{-1}$

$R$

Molar gas constant

$\mathrm{J} \mathrm{K}^{-1} \mathrm{~mol}^{-1}$

$R e$

Reynolds number $\left(R e=v d_{e} / v\right)$

Dimensionless

$S$

Flow channel height

$\mathrm{cm}$

$T$

Temperature

K

$\mathrm{V}$

Mean linear flow velocity past the electrode surface

$\mathrm{cm} \mathrm{s}^{-1}$

$Z$

Electron stoichiometry

Dimensionless

$\alpha$

Charge transfer coefficient

Dimensionless

$\varepsilon$

Volumetric porosity

Dimensionless

$\eta$

Overpotential

V

$v$

Kinematic viscosity of fluid

$\mathrm{cm}^{2} \mathrm{~s}^{-1}$

$\Psi$

Current ratio to planar electrode

Dimensionless 


\section{Abbreviations}

BET Brunauer-Emmett-Teller gas adsorption theory

CT (X-ray) computed tomography

CVP Chemical vapour deposition

DSA Dimensionally stable anode

EDS Energy-dispersive X-ray spectroscopy

GDL Gas diffusion layer

ITP Inert turbulence promoter

PVD Physical vapour deposition

$\mathrm{Pt} / \mathrm{Ti} \quad$ Platinised titanium

RFB Redox flow battery

RVC Reticulated vitreous carbon

SEM Scanning electron microscopy 
Table 1. Origin, manufacturing method, Pt loading and hydraulic dimensions of the Pt/Ti flow cell electrodes.

\begin{tabular}{|c|c|c|c|c|c|c|c|}
\hline Electrode & Origin & $\begin{array}{c}\text { Manufacturing } \\
\text { method }\end{array}$ & $\begin{array}{l}\text { Lengt } \\
\mathrm{h}, L / \\
\mathrm{cm}\end{array}$ & $\begin{array}{l}\text { Breadth } \\
, B / \mathrm{cm}\end{array}$ & $\begin{array}{l}\text { Height, } \\
S / \mathrm{cm}\end{array}$ & $\begin{array}{c}\text { Equivalent } \\
\text { hydraulic } \\
\text { diameter, } d_{e} / \\
\mathrm{cm}\end{array}$ & $\begin{array}{c}\text { Average } \\
\text { volumetric Pt } \\
\text { loading, mg } \\
\mathrm{cm}^{-3}\end{array}$ \\
\hline $\begin{array}{c}\mathrm{Pt} / \text { Ti plate } \\
+ \text { ITP }\end{array}$ & Supplied & Electrodeposition & 6.0 & 4.0 & 0.36 & 0.661 & NA \\
\hline $\begin{array}{c}\mathrm{Pt} / \mathrm{Ti} \text { felt } \\
\mathrm{A}\end{array}$ & In-house & $\begin{array}{c}\text { Potentiostatic } \\
\text { electrodeposition }\end{array}$ & 6.0 & 4.0 & 0.36 & 0.661 & 4.6 \\
\hline $\begin{array}{c}\mathrm{Pt} / \mathrm{Ti} \text { felt } \\
\mathrm{B}\end{array}$ & In-house & $\begin{array}{c}\text { Galvanostatic } \\
\text { electrodeposition }\end{array}$ & 6.0 & 4.0 & 0.36 & 0.661 & 9.3 \\
\hline $\begin{array}{c}\mathrm{Pt} / \mathrm{Ti} \text { felt } \\
\mathrm{C}\end{array}$ & In-house & $\begin{array}{c}\text { Galvanostatic } \\
\text { electrodeposition }\end{array}$ & 6.0 & 4.0 & 0.36 & 0.661 & 18.3 \\
\hline
\end{tabular}


Table 2. Conditions for the electrodeposition of platinum on titanium and felt in this work.

\begin{tabular}{cc}
\hline Variable & Value \\
\hline Hexachloroplatinic(IV) acid concentration & $20 \mathrm{mg} \mathrm{dm}^{-3}$ \\
NaOH concentration & $0.1 \mathrm{~mol} \mathrm{dm}^{-3}$ \\
Kinematic viscosity of water, $v$ & $3.9 \times 10^{-3} \mathrm{~cm}^{2} \mathrm{~s}^{-1}$ \\
Electrolyte mean linear flow rate, $\mathrm{v}$ & $8.0 \mathrm{~cm} \mathrm{~s}^{-1}$ \\
Reynolds number, $R e$ & $\approx 1355$ \\
Temperature, $T$ & $75^{\circ} \mathrm{C}$ \\
\hline
\end{tabular}


Table 3. Estimated charge transfer current ratios for the evaluated porous electrodes $v s$. the $\mathrm{Pt} / \mathrm{Ti}$ plate (+ ITP) electrode and their respective theoretical values of $A_{e}$ for $\mathrm{H}$ adsorption based on their charge transfer-controlled current for the reduction of $0.1 \mathrm{~mol} \mathrm{dm}^{-3} \mathrm{Ce}(\mathrm{IV})$ at $\eta$ $=-20.0 \mathrm{mV}$.

\begin{tabular}{|c|c|c|c|c|c|}
\hline \multirow{5}{*}{ Electrode } & Open-circuit & Charge & Current ratio & Active & Volumetric \\
\hline & potential $v s$. & transfer & to $\mathrm{Pt} / \mathrm{Ti}$ plate & electrode area & active electrode \\
\hline & $\mathrm{Hg} \mid \mathrm{Hg}_{2} \mathrm{SO}_{4 \text { (satd) }}$ & current, $I_{C T} /$ & electrode + & for $\mathrm{H}$ & area for $\mathrm{H}$ \\
\hline & $E_{0} / \mathrm{mV}$ & $\mathrm{mA}$ & ITP, $\Psi$ & adsorption, $A_{a}$ & adsorption, $A_{e} /$ \\
\hline & & & & $/ \mathrm{cm}^{2}$ & $\mathrm{~cm}^{-1}$ \\
\hline $\mathrm{Pt} /$ Ti plate + & $+883.5 \pm 2.9$ & $-13.5 \pm 2.6$ & 1.0 & $748.8 \pm 16.8$ & $87.9 \pm 2.0$ \\
\hline \multicolumn{6}{|l|}{ ITP } \\
\hline $\mathrm{Pt} / \mathrm{Ti}$ felt $\mathrm{A}$ & $+884.4 \pm 1.1$ & $-164.3 \pm 22.8$ & 12.2 & $\approx 9,100$ & $\approx 1,050$ \\
\hline $\mathrm{Pt} /$ Ti felt B & $+881.3 \pm 1.2$ & $-245.9 \pm 32.0$ & 18.2 & $\approx 13,600$ & $\approx 1,570$ \\
\hline $\mathrm{Pt} / \mathrm{Ti}$ felt $\mathrm{C}$ & $+896.2 \pm 2.9$ & $-275.6 \pm 16.5$ & 20.4 & $\approx 15,300$ & $\approx 1,770$ \\
\hline
\end{tabular}




\section{Figure captions}

Figure 1. Experimental arrangement for the electrodeposition of platinum on titanium felt using a rectangular flow channel, a) using a direct current power supply under galvanostatic control and $b$ ) at a constant electrode potential using a potentiostat.

Figure 2. a) Rectangular channel of the flow cell used during the electroplating of the titanium felt. An ion exchange membrane separates the positive and negative half-cells. For clarity, acrylic polymer bodies have been omitted and the current collectors have been cut to the same size of the electrodes. The plating solution flows upward in the vertical ( $Z$ axis) direction. b) Disposition of the Pt/Ti felt electrode and its current collector. The grid pattern represents the porous felt.

Figure 3. SEM images of the external surface (in X-Z plane) of Pt/Ti felt C (left) and $\mathrm{Pt} /$ Ti plate (right) electrode materials at various magnifications: a) $\mathrm{Pt} / \mathrm{Ti}$ felt C 20×, b) Pt/Ti felt C 1,000×, c) Pt/Ti felt C 1,000×; and a) Pt/Ti plate 20×, b) $\mathrm{Pt} / \mathrm{Ti}$ plate $1,000 \times, \mathrm{c}) \mathrm{Pt} / \mathrm{Ti}$ plate $1,000 \times$. In a) the plating solution flows from left to right during the electrodeposition process.

Figure 4. SEM images of the platinum coating on the external surface (in X-Z plane) of the Pt/Ti felt electrodes: a) felt A, b) felt B, c) felt C.

Figure 5. SEM images of the platinum coating on the interior of the $\mathrm{Pt} / \mathrm{Ti}$ felt $\mathrm{C}$ electrode (following the $\mathrm{Y}$ axis): $\mathrm{a}$ ) at the plane adjacent to the membrane, $\mathrm{b}$ ) at $300 \mu$ from the membrane, c) at $1.0 \mathrm{~mm}$ from the membrane, d) at $1.5 \mathrm{~mm}$ from the membrane, e) at the plane adjacent to the current collector.

Figure 6. EDS analysis of a) the platinum coating nucleation, b) the titanium substrate corresponding to the SEM image.

Figure 7. EDS mapping of a cross-section of the Pt/Ti felt $\mathrm{C}$ electrode. The vertical axis in the image represents the $\mathrm{Y}$-axis of the cell and the top plane the surface adjacent to the membrane during electrodeposition. a) SEM image of 
sample, b) elemental mapping of titanium (in blue), and c) elemental mapping of platinum (in green).

Figure 8. CT images of parallelepiped volume sections of a) bare Ti felt and b) the $\mathrm{Pt} / \mathrm{Ti}$ felt $\mathrm{C}$ electrode showing an area with higher coverage of platinum (bright blue). The vertical axis in the image represents the $\mathrm{Y}$ axis of the cell.

Figure 9. CT images of a section of the Pt/Ti felt $\mathrm{C}$ electrode showing the platinum (bright green and yellow) coating around the titanium felt fibres (light blue). a) Y-Z plane bisecting the scan region, b) X-Z plane at a depth of approximately $120 \mu \mathrm{m}$ into the electrode. For clarity, contrast artefacts were digitally replaced with the background colour.

Figure 10. CT image of the cross section of the $\mathrm{Pt} / \mathrm{Ti}$ felt $\mathrm{C}$ electrode indicating the platinum deposit distribution. Bright green features are platinum; blue features are titanium, dark blue being air. The vertical axis in the image represents the $\mathrm{Y}$ axis of the cell.

Figure 11. Linear sweep voltammetry of various $\mathrm{Pt} / \mathrm{Ti}$ electrodes for the reduction of $0.1 \mathrm{~mol} \mathrm{dm}{ }^{-3} \mathrm{Ce}(\mathrm{IV})$ at $25^{\circ} \mathrm{C}$ near the open-circuit potential showing the the equilibrium potential, $E_{0}$, and charge transfer current at an overpotential of$20 \mathrm{mV}$ for each electrode material.

Figure 12. a) Cyclic voltammogram for a $0.05 \mathrm{~cm}^{2}$ area of the $\mathrm{Pt} / \mathrm{Ti}$ planar electrode in $1.0 \mathrm{~mol} \mathrm{dm}{ }^{-3} \mathrm{H}_{2} \mathrm{SO}_{4}$ at $25^{\circ} \mathrm{C}$. Linear potential sweep rate: $1.0 \mathrm{~V} \mathrm{~s}^{-1}$. b) Cyclic voltammogram of a typical polished $\mathrm{Pt}$ disc electrode $\left(0.07 \mathrm{~cm}^{2}\right)$ for comparison. The regions of charge used for area estimation are shaded. 


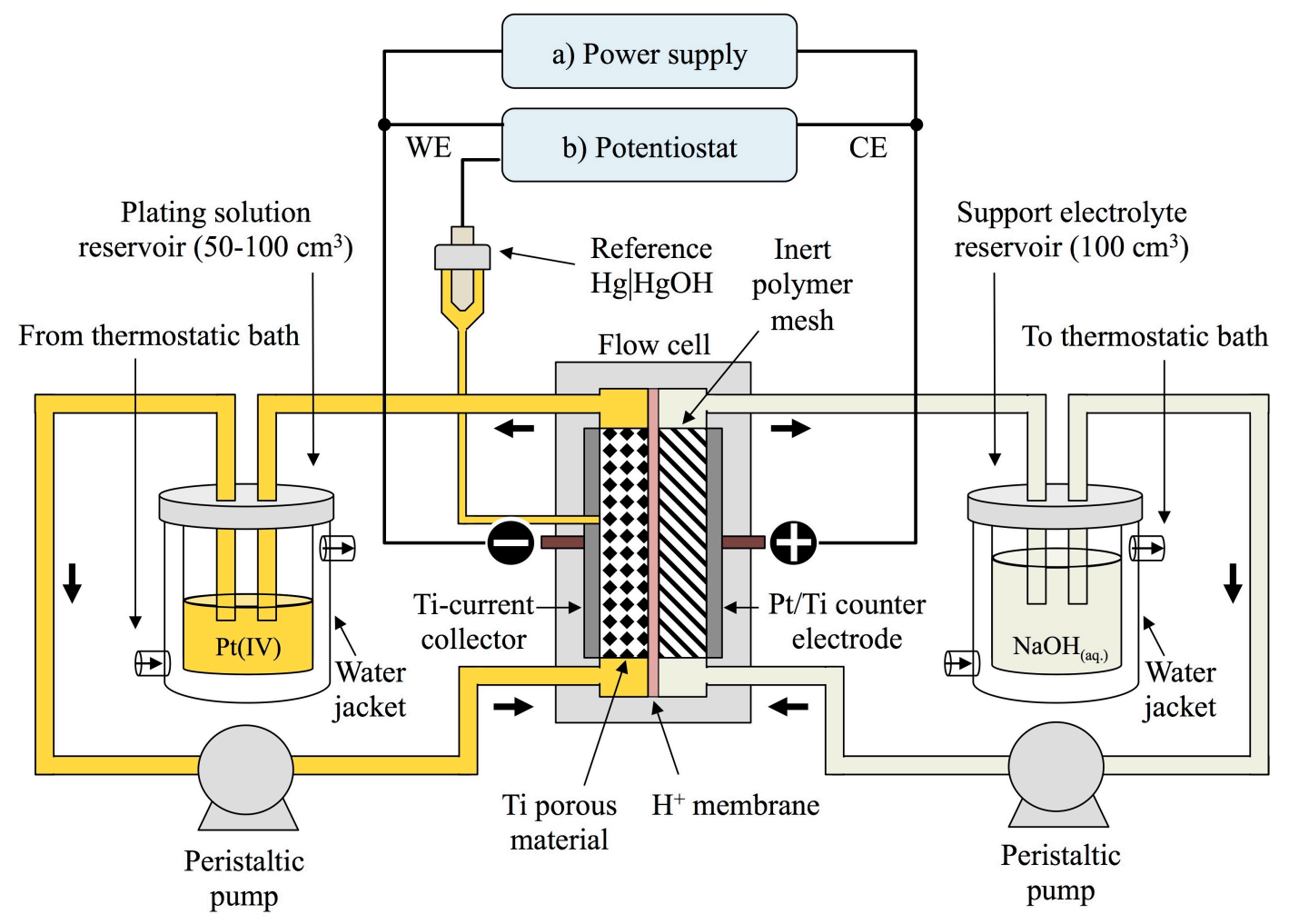

Figure 1. 


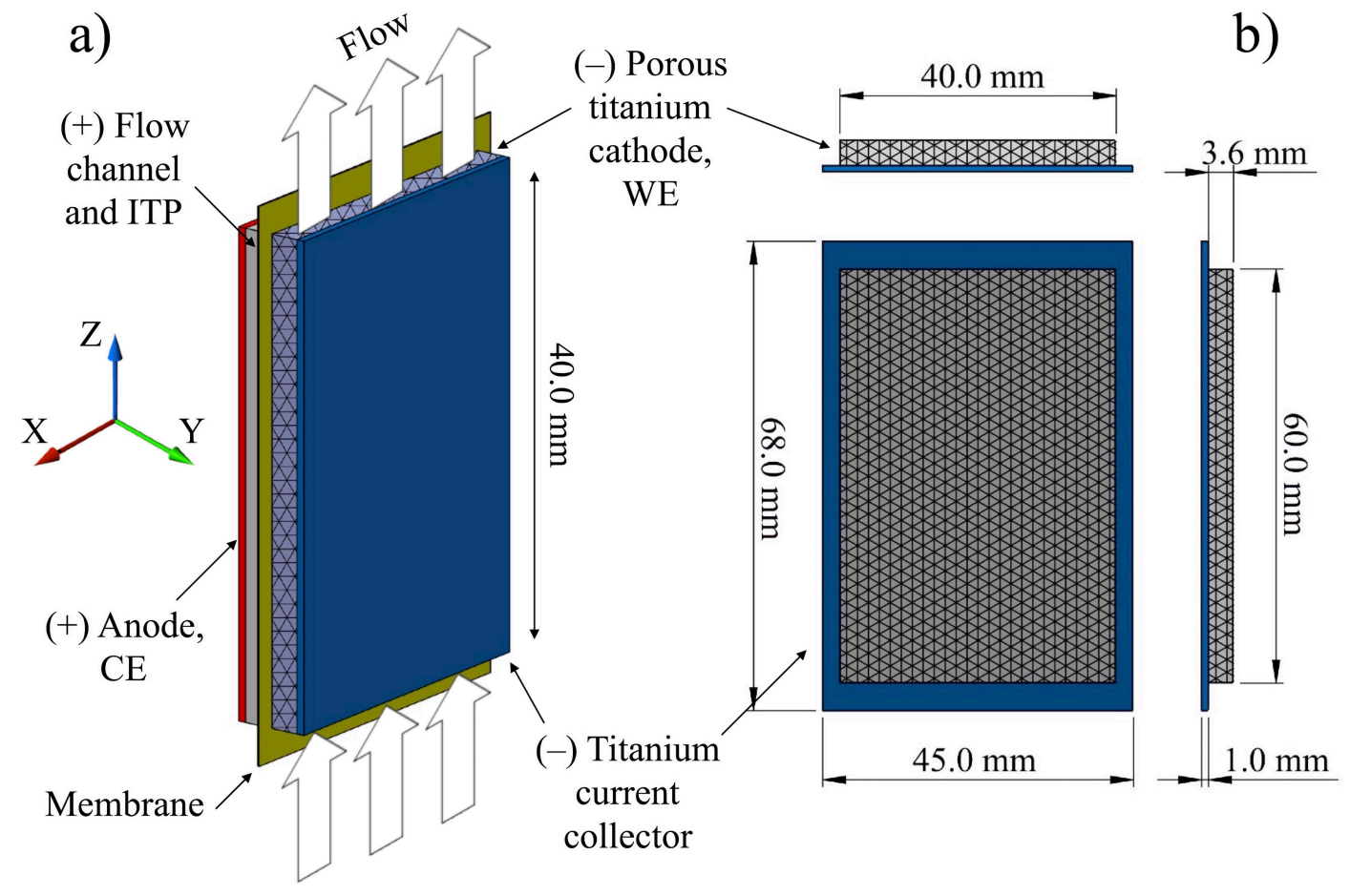

Figure 2. 


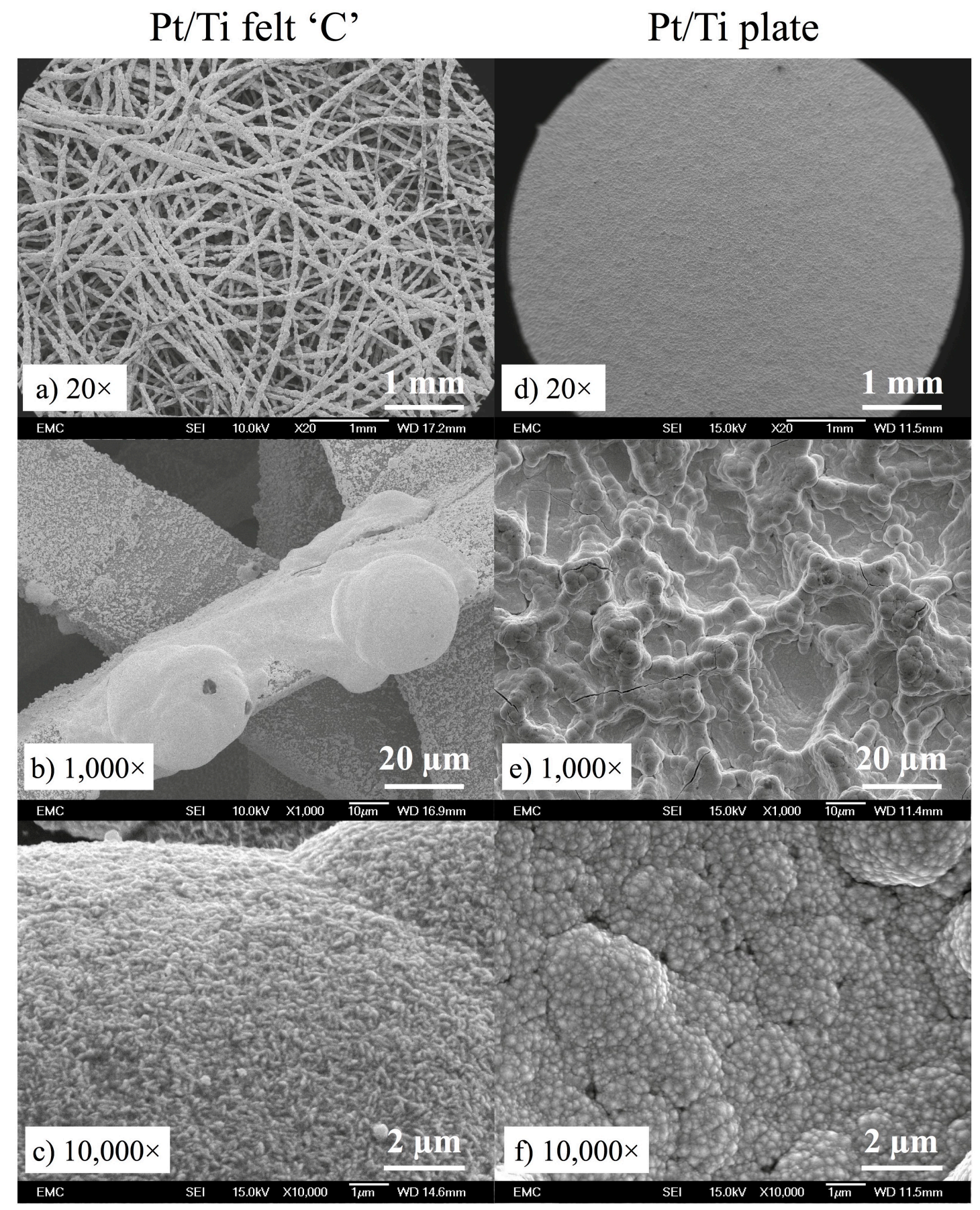

Figure 3. 


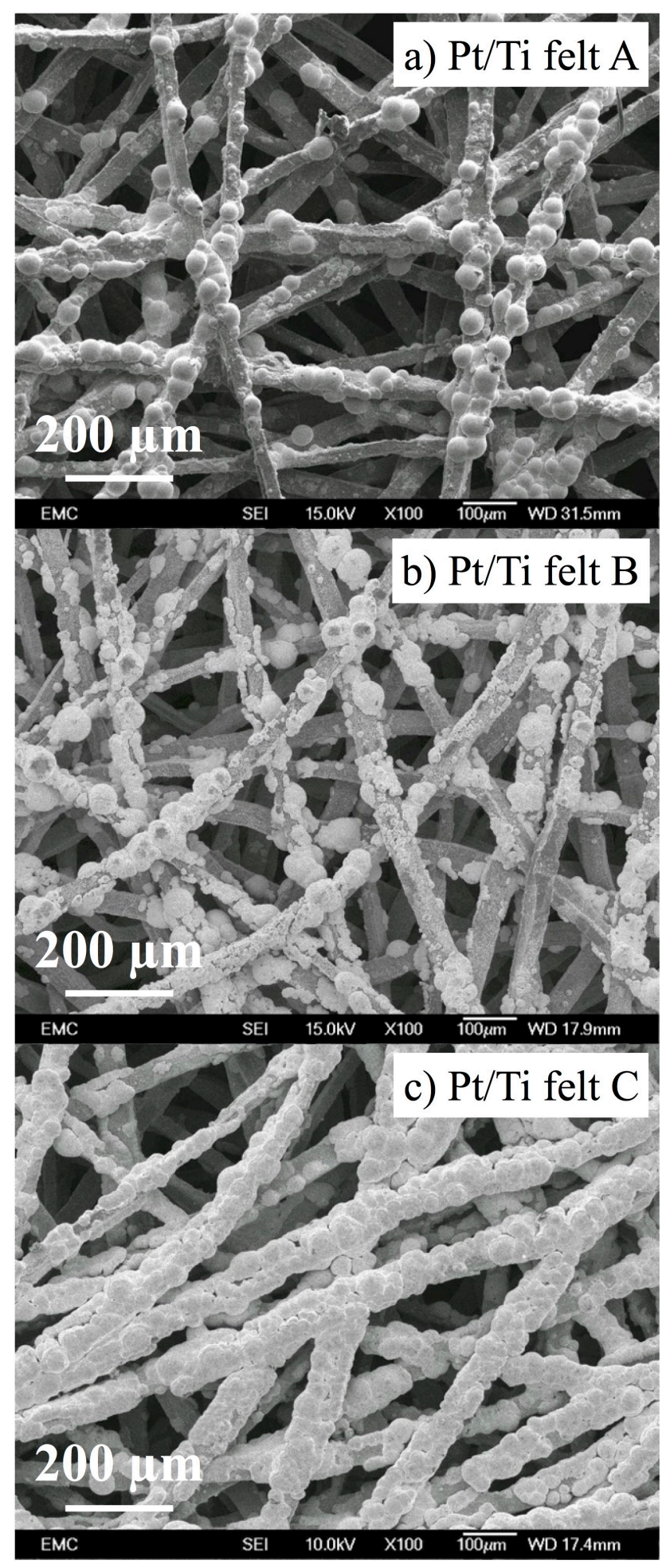

Figure 4. 


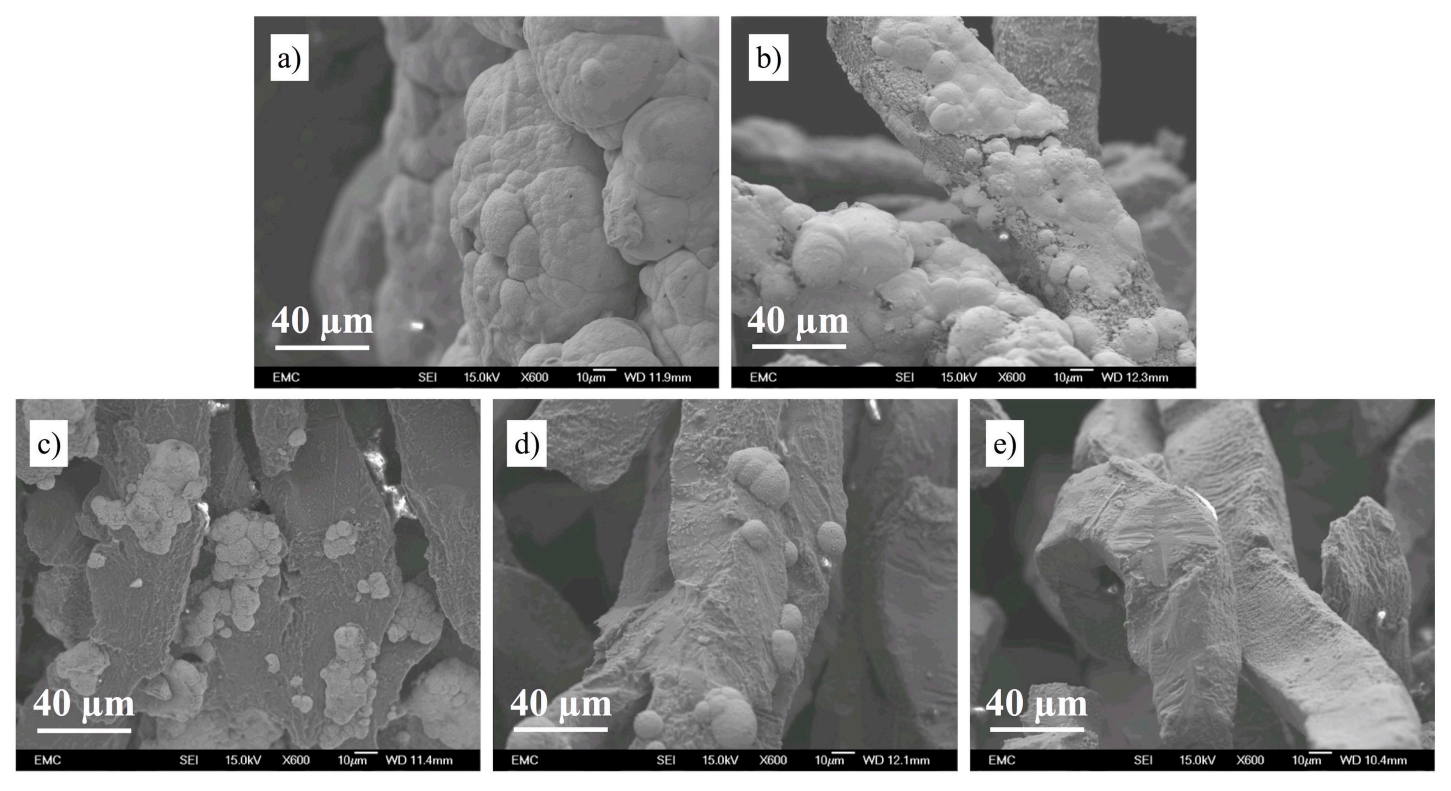

Figure 5. 

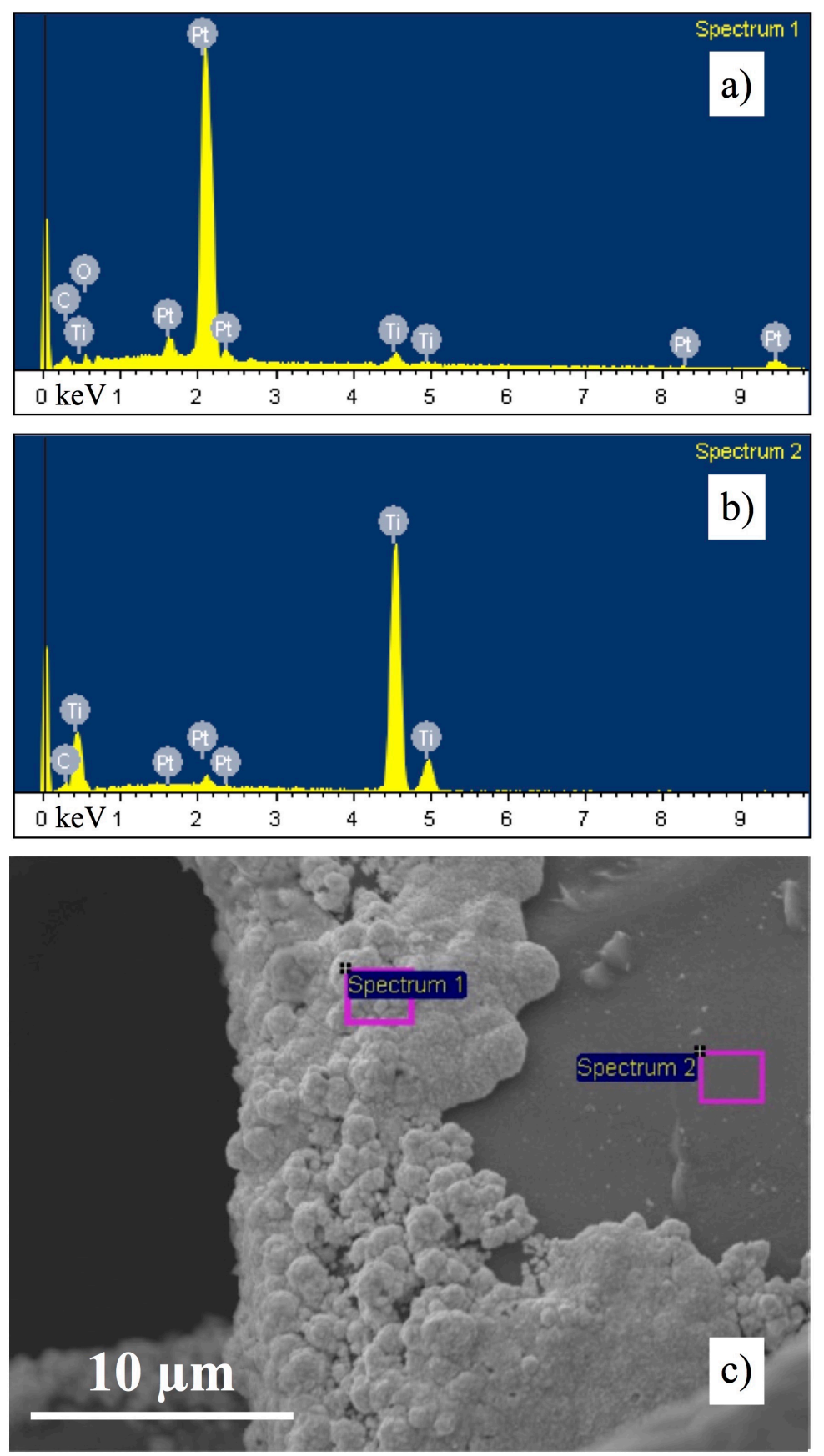

Figure 6. 


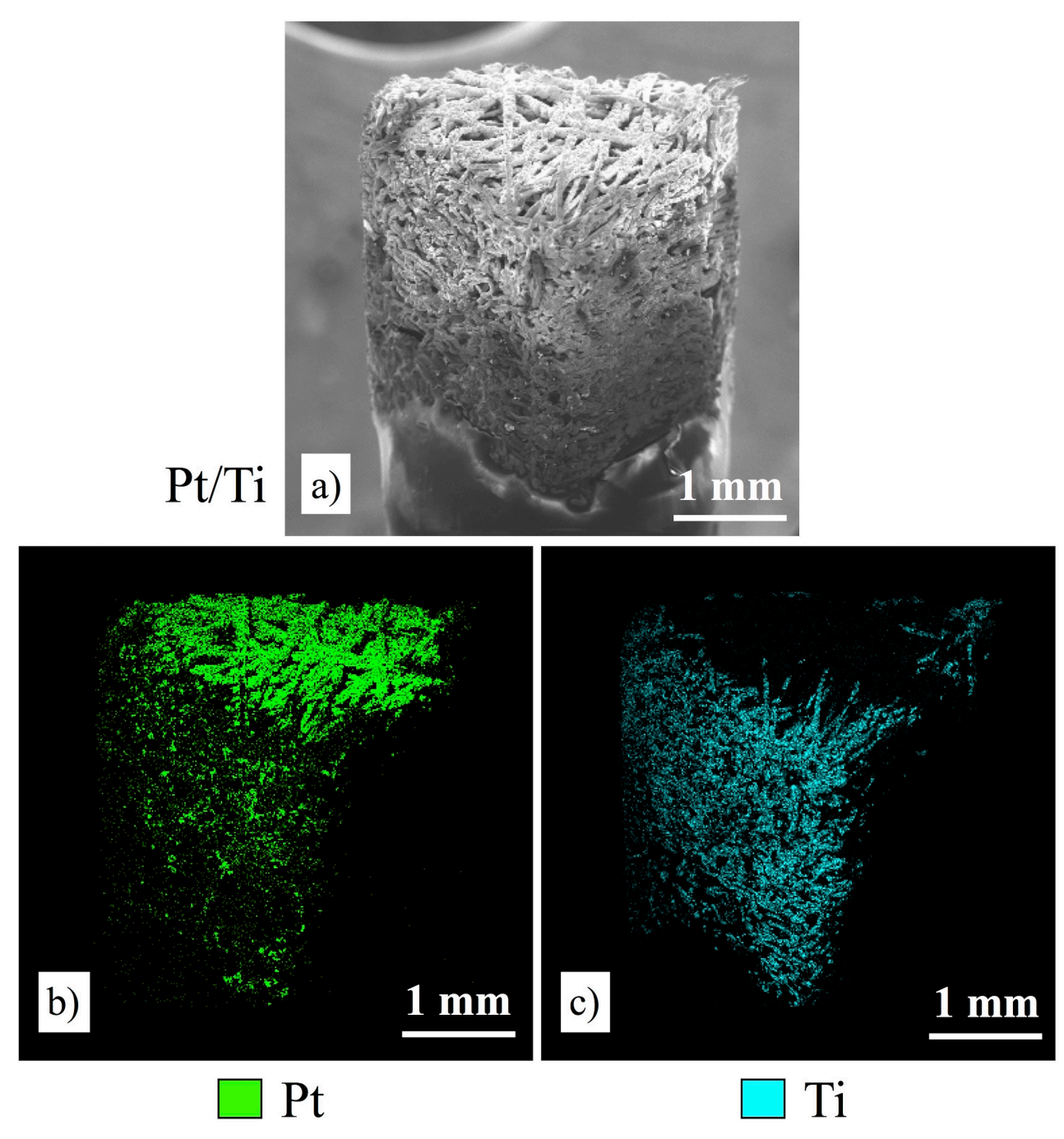

Figure 7. 

a) Bare titanium felt
b) $\mathrm{Pt} / \mathrm{Ti}$ felt $\mathrm{C}$ showing Pt deposits
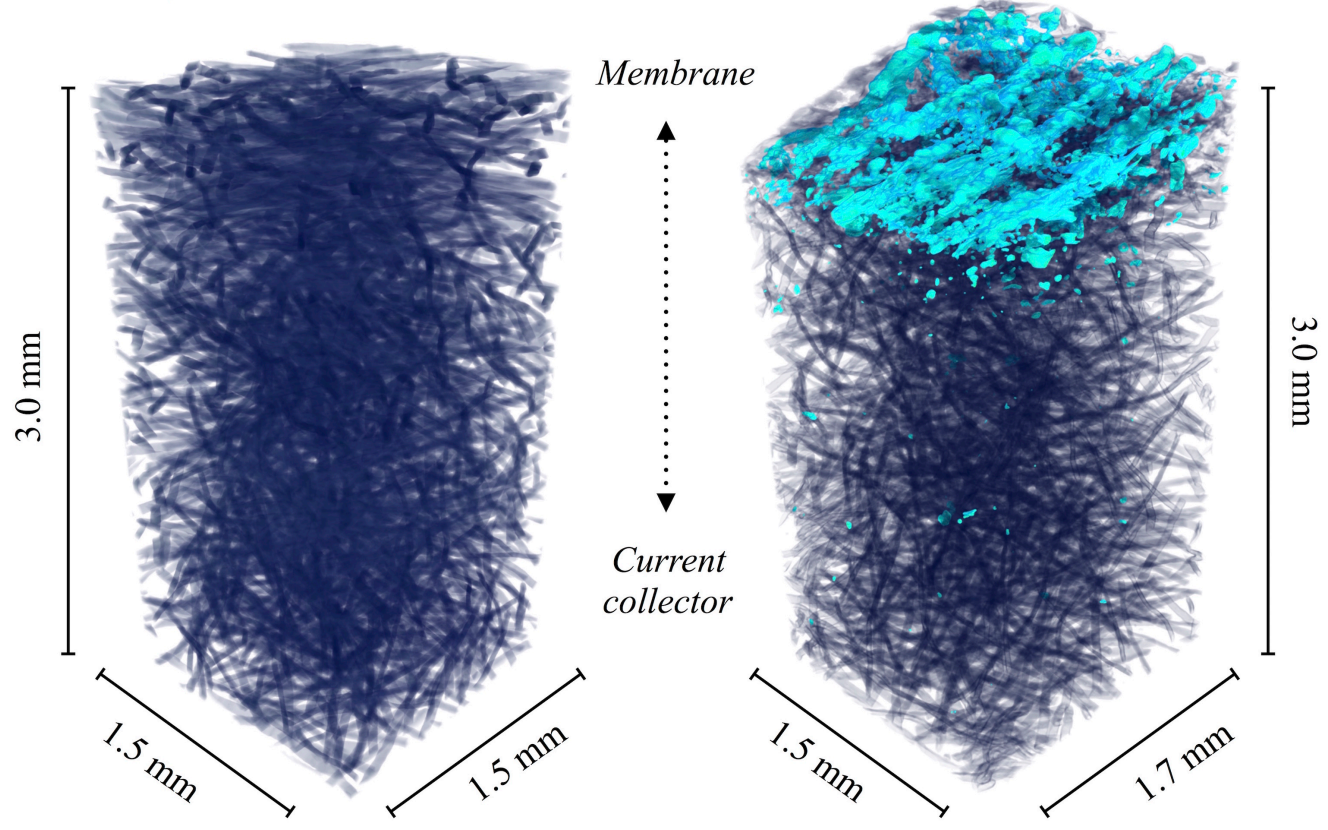

Figure 8. 


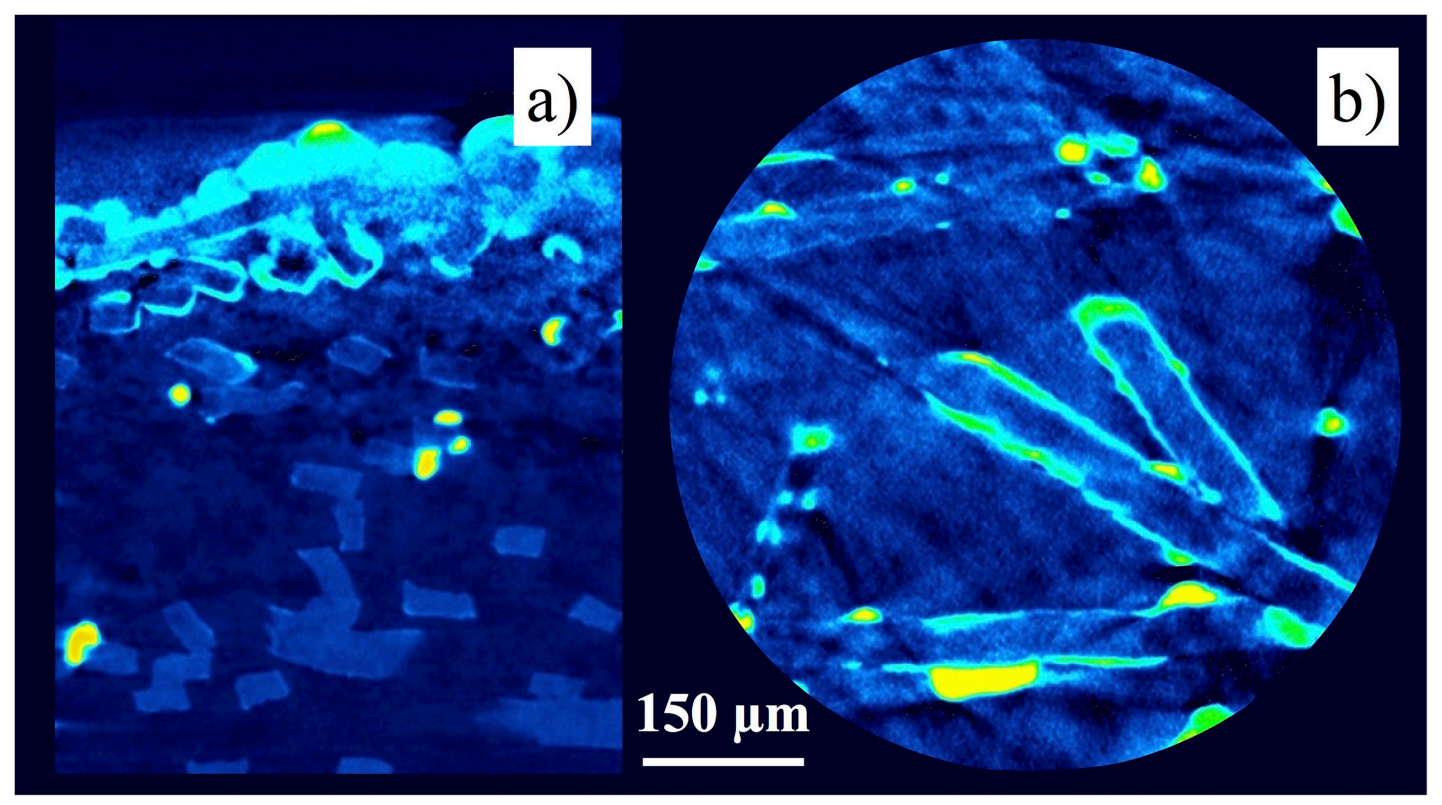

Figure 9. 


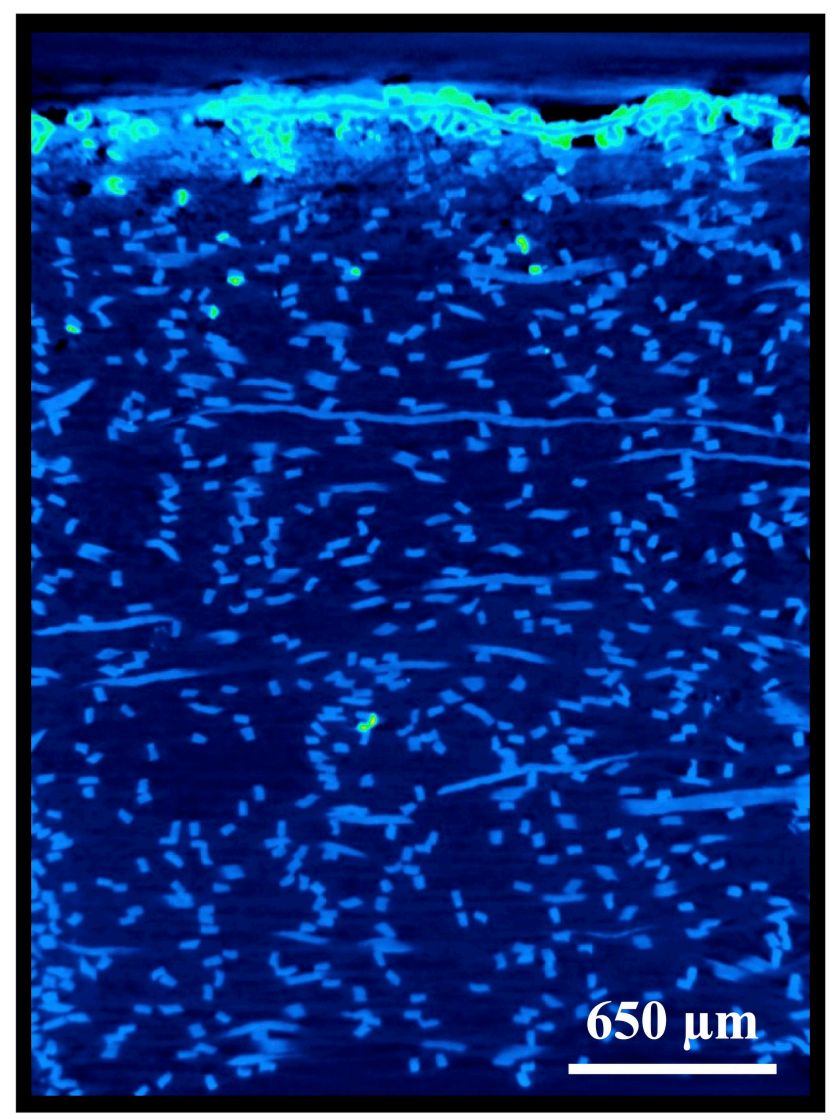

Figure 10. 


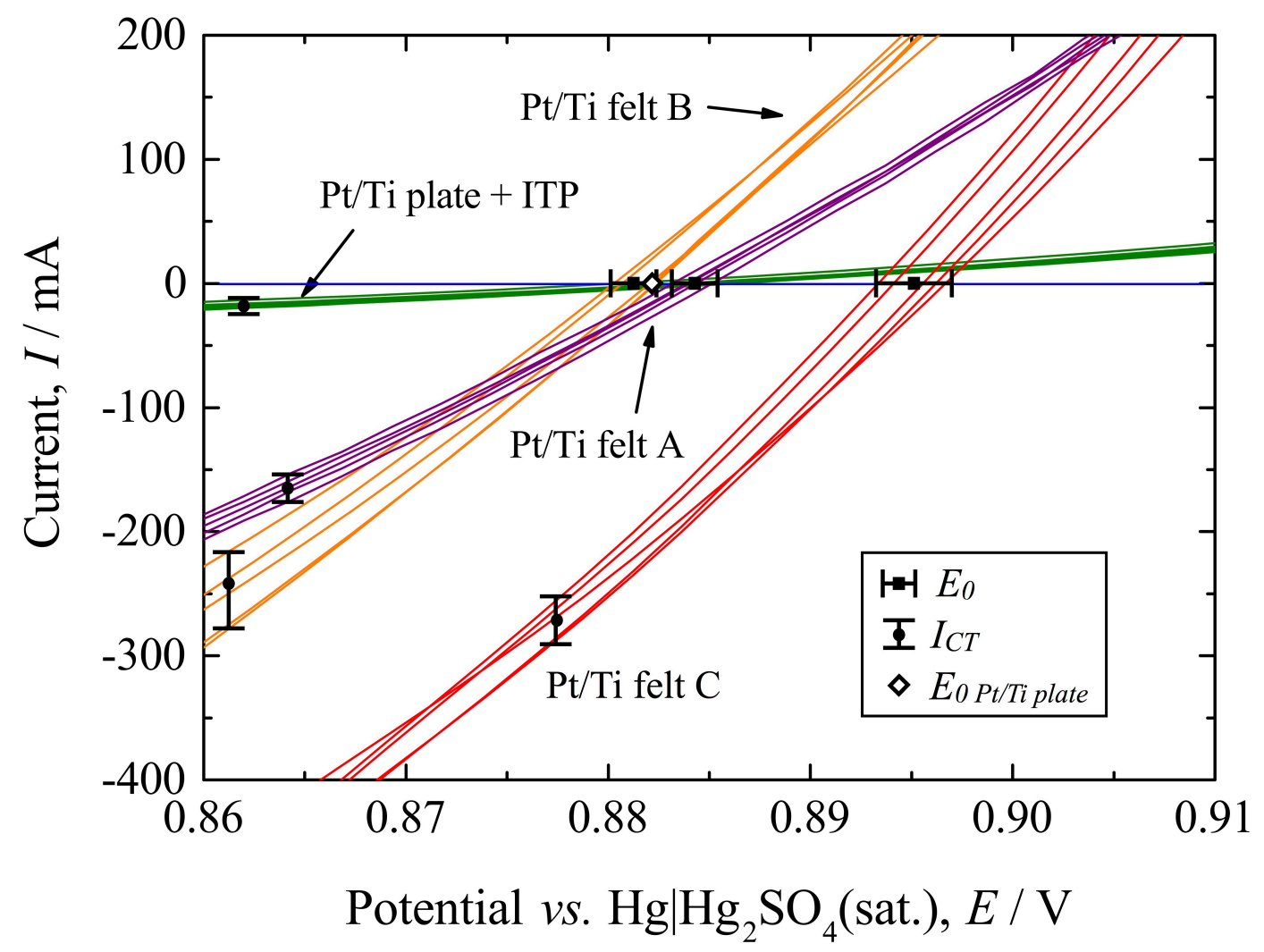

Figure 11. 


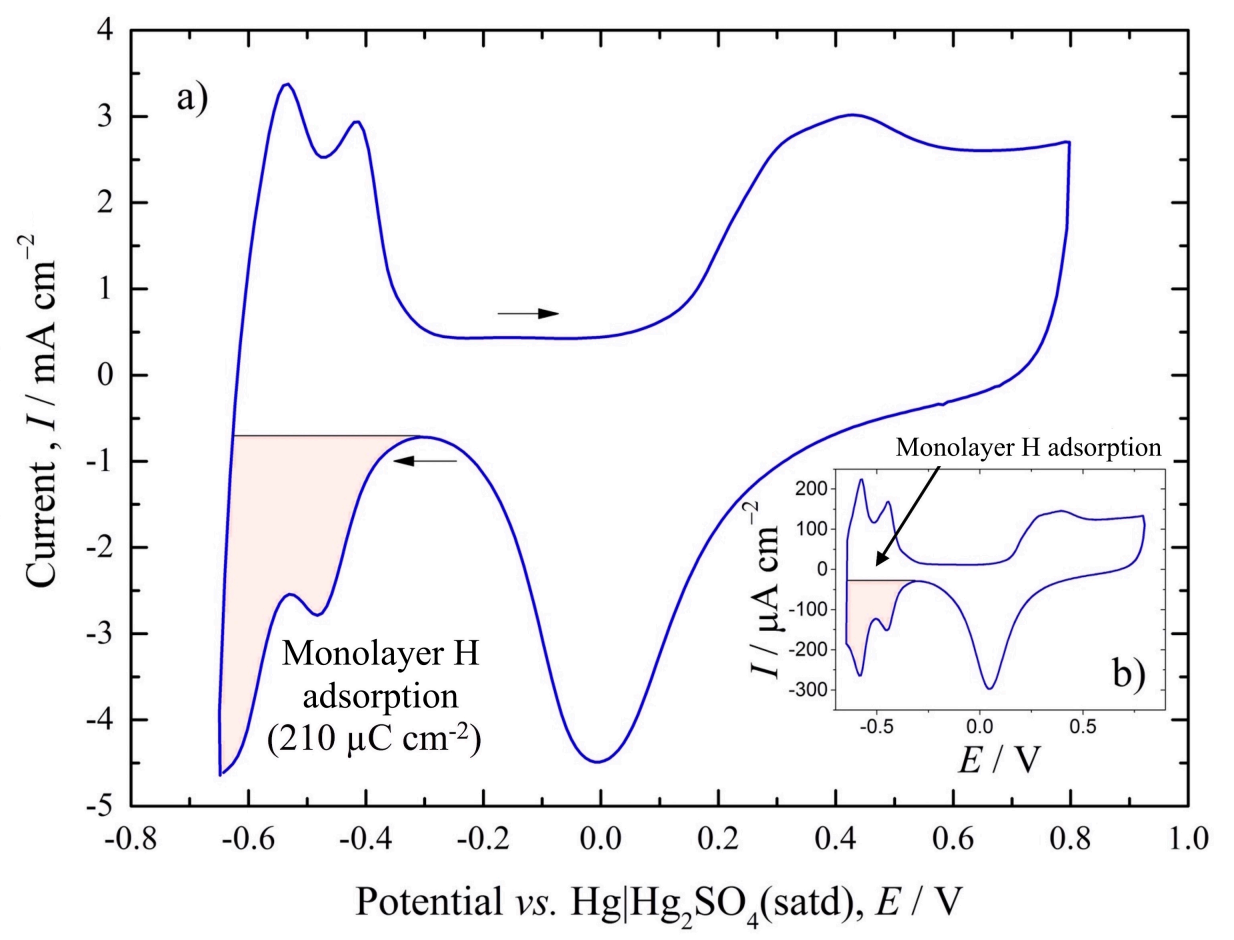

Figure 12. 